\title{
Hidden biosphere in an oxygen-deficient Atlantic open-ocean eddy: future implications of ocean deoxygenation on primary production in the eastern tropical North Atlantic
}

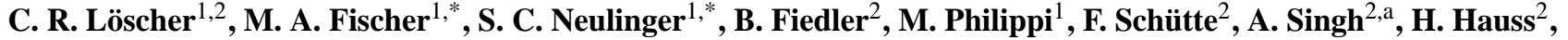 \\ J. Karstensen ${ }^{2}$, A. Körtzinger ${ }^{2,3}$, S. Künzel ${ }^{4}$, and R. A. Schmitz ${ }^{1}$ \\ ${ }^{1}$ Department of biology, Institute for General Microbiology, Kiel, Germany \\ ${ }^{2}$ GEOMAR, Helmholtz Centre for Ocean Research Kiel, Kiel University, Kiel, Germany \\ ${ }^{3}$ Christian-Albrechts-Universität zu Kiel, Kiel, Germany \\ ${ }^{4}$ Max Planck Institute for Evolutionary Biology, Plön, Germany \\ anow at: Physical Research Laboratory, Geosciences Division, Ahmedabad, 380 009, India \\ *These authors contributed equally to this work.
}

Correspondence to: C. R. Löscher (cloescher@geomar.de)

Received: 13 July 2015 - Published in Biogeosciences Discuss.: 27 August 2015

Revised: 20 November 2015 - Accepted: 10 December 2015 - Published: 21 December 2015

\begin{abstract}
The eastern tropical North Atlantic (ETNA) is characterized by a highly productive coastal upwelling system and a moderate oxygen minimum zone with lowest open-ocean oxygen $\left(\mathrm{O}_{2}\right)$ concentrations of approximately $40 \mu \mathrm{mol} \mathrm{kg}{ }^{-1}$. The recent discovery of re-occurring mesoscale eddies with close to anoxic $\mathrm{O}_{2}$ concentrations $\left(<1 \mu \mathrm{mol} \mathrm{kg}{ }^{-1}\right)$ located just below the mixed layer has challenged our understanding of $\mathrm{O}_{2}$ distribution and biogeochemical processes in this area.

Here, we present the first microbial community study from a deoxygenated anticyclonic modewater eddy in the open waters of the ETNA. In the eddy, we observed significantly lower bacterial diversity compared to surrounding waters, along with a significant community shift. We detected enhanced primary productivity in the surface layer of the eddy indicated by elevated chlorophyll concentrations and carbon uptake rates of up to three times as high as in surrounding waters. Carbon uptake rates below the euphotic zone correlated to the presence of a specific high-light ecotype of Prochlorococcus, which is usually underrepresented in the ETNA. Our data indicate that high primary production in the eddy fuels export production and supports enhanced respiration in a specific microbial community at shallow depths, below the mixed-layer base. The transcription of the key functional marker gene for dentrification, nirS, further indicated
\end{abstract}

a potential for nitrogen loss processes in $\mathrm{O}_{2}$-depleted core waters of the eddy. Dentrification is usually absent from the open ETNA waters.

In light of future projected ocean deoxygenation, our results show that even distinct events of anoxia have the potential to alter microbial community structure with critical impacts on primary productivity and biogeochemical processes of oceanic water bodies.

\section{Introduction}

The eastern tropical North Atlantic (ETNA) region is influenced by an eastern boundary upwelling system (EBUS) off northwest Africa, which along with nutrient supply via Saharan dust deposition, fuels one of the most productive ocean regions in the world. A moderate oxygen minimum zone (OMZ) is associated with this EBUS, with lowest oxygen $\left(\mathrm{O}_{2}\right)$ concentrations just below $40 \mu \mathrm{mol} \mathrm{kg} \mathrm{kg}^{-1}$ present at intermediate depths (Chavez and Messié, 2009; Jickells et al., 2005; Karstensen et al., 2008).

$\mathrm{O}_{2}$ records over several years from the Cape Verde Ocean Observatory (CVOO) mooring (located at $17^{\circ} 35^{\prime} \mathrm{N}$, $24^{\circ} 15^{\prime} \mathrm{W}$, Fig. 1) confirmed the well-ventilated character of the ETNA. However, the observation of distinct events 
of very low- $\mathrm{O}_{2}$ concentrations $\left(<1 \mu \mathrm{mol} \mathrm{kg}{ }^{-1}\right)$ at depths around 40 to $100 \mathrm{~m}$ over periods of more than 1 month challenged our understanding of the biogeochemistry in that area (Karstensen et al., 2015a). The meridional current structure observed during these low- $\mathrm{O}_{2}$ events revealed the passage of anticyclonic modewater eddies (ACME) crossing the CVOO mooring (Karstensen et al., 2015a). The ocean is filled with eddies (Chelton et al., 2011) but only a few of them have the dynamical and biogeochemical boundary conditions that support formation of a low- $\mathrm{O}_{2}$ core. Anomalous low salinity within the ETNA low- $\mathrm{O}_{2}$ eddies suggested the water mass originated from the EBUS off Mauritania, which was confirmed by analyzing sea-level anomaly data. In combination with other data from the upwelling region, Karstensen et al. (2015a) showed that $\mathrm{O}_{2}$ concentrations decreased over a period of a few months during westward propagation of the eddies into the open north Atlantic Ocean. Respiration in these eddies was estimated to be about three to five times higher than typical subtropical gyre values (Karstensen et al., 2008).

Mesoscale eddies are increasingly recognized as biogeochemical hot-spots of basin-wide relevance for the world's oceans (Altabet et al., 2012; Baird et al., 2011; Chelton et al., 2011; McGillicuddy et al., 2007; Oschlies and Garcon, 1998; Stramma et al., 2013). Upward nutrient supply to the euphotic zone through mesoscale eddy dynamics enables intense primary productivity (Lévy et al., 2001, 2012; McGillicuddy et al., 2007). Classically, primary producers in the ETNA open waters area are dominated by a range of diatom clades, flagellates and cyanobacteria (Franz et al., 2012), but so far no specific information on the primary producers in productive ETNA eddies has been reported. As a result of enhanced primary production in the surface, increased organic matter export flux below the euphotic zone is expected, which in turn supports increased respiration at intermediate depths. Indeed, particle maxima a few meters above the $\mathrm{O}_{2}$ minimum have been reported based on autonomous observations of $\mathrm{O}_{2}$-depleted eddies in the ETNA (Karstensen et al., 2015a), indicating enhanced organic matter export and providing environments of enhanced remineralization (Ganesh et al., 2014). Observations from a low$\mathrm{O}_{2}$ eddy from the ETNA revealed a remarkable impact on all productivity-related processes in that particular system (Fischer et al., 2015). Estimated productivity was three-fold higher in the surface layer compared to surrounding waters along with a multiple times increase in mass flux in bathypelagic during the eddy passage. Furthermore, Fiedler et al. (2015) determined export flux derived from carbon remineralization rates within the eddy and found a 3-4-fold enhanced export flux compared to background conditions in the open-ocean ETNA.

$\mathrm{O}_{2}$-depleted conditions are supposed to act as a critical switch for the marine microbial community, both with regard to functionality and diversity. $\mathrm{O}_{2}$ begins to limit oxidative pathways and reductive pathways are induced (Stewart et al.,
A

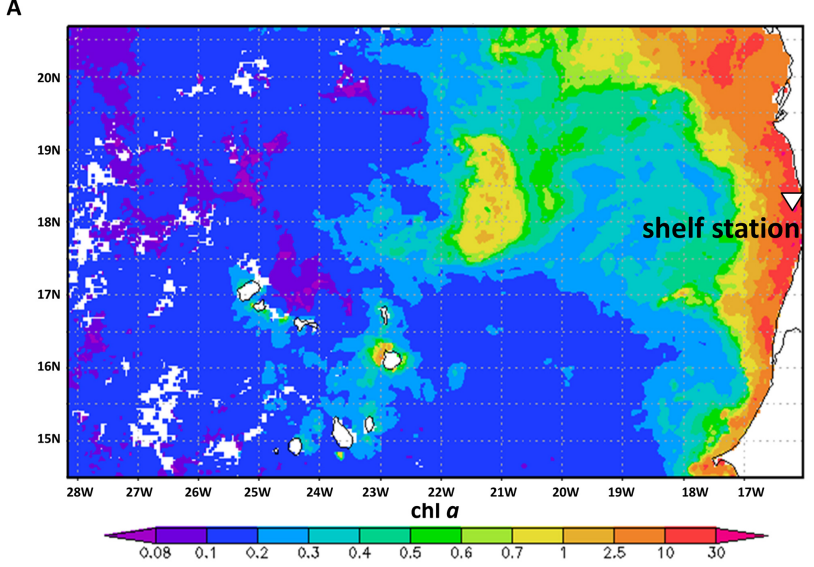

B
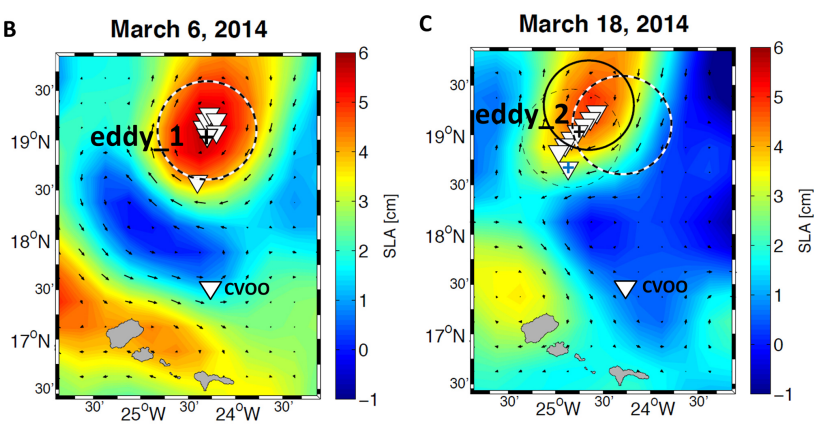

Figure 1. (a) MODIS-Aqua $4 \mathrm{~km}$ monthly mean chl $a$ distribution in the ETNA $\left(\mathrm{mg} \mathrm{m}^{-3}\right)$ in November 2013. Markedly increased chl $a$ concentrations are associated with the low-oxygen ACME, located between $21 \mathrm{c}$ and $22^{\circ} \mathrm{W}$ and 17.5 and $19^{\circ} \mathrm{N}$. Analyses and visualizations were produced with the Giovanni online data system, developed and maintained by the NASA GES DISC. Eddy location indicated by sea level anomaly (SLA) during the time of the two surveys: (b) first eddy observation; + denotes the eddy_1 station, (c) second eddy observation + denotes the eddy_2 station, an additional station was sampled at the eddy rim for $\mathrm{C}$ uptake measurements, indicated by the blue + . White triangle marks the sampling station for the potential source water of the eddy. The dashed circles indicate the location of the eddy during the R/V Islandia survey, the black circle indicates the eddy location during the R/V Meteor survey, and the dashed black line indicates the direction of eddy propagation. Sampling stations are shown with white triangles.

2011; Ulloa et al., 2012; Wright et al., 2012). A loss in microbial diversity related to vertical $\mathrm{O}_{2}$ gradients has previously been described for the Pacific Ocean (Beman and Carolan, 2013; Bryant et al., 2012), but to date no comparable data are available from the ETNA. $\mathrm{O}_{2}$-loss related microbial community shifts and modified functionality are supposed to favor heterotrophic communities dominated by Flavobacteria, $\alpha$ and $\gamma$-Proteobacteria, which efficiently recycle organic matter (Buchan et al., 2014). Furthermore, marine nitrogen (N) and carbon $(\mathrm{C})$ cycling are significantly altered under low $\mathrm{O}_{2}$ conditions (Vaquer-Sunyer and Duarte, 2008; Wright et al., 2012). Substantial N loss (Altabet et al., 2012) along with enhanced nitrous oxide production (Arévalo-Martínez et al., 
2015) has been described in low- $\mathrm{O}_{2}$ eddies in the OMZ off Peru in the eastern tropical South Pacific.

Classically, the $\mathrm{N}$ cycle in the open ETNA is assumed to be dominated by nitrification. An $\mathrm{N}$ loss signal is not present due to comparably high background $\mathrm{O}_{2}$ concentrations ( $\geq 40 \mu \mathrm{mol} \mathrm{kg}{ }^{-1}$, (Löscher et al., 2012; Ryabenko et al., 2012)). However, any drop in $\mathrm{O}_{2}$ concentration in the water column, as potentially induced by the low- $\mathrm{O}_{2}$ eddies, could potentially activate anammox and/or denitrification. During recent decades, the ETNA OMZ has been expanding both in terms of vertical extent and intensity and is predicted to expand further in the future (Stramma et al., 2008) with unknown consequences for the ecology and biogeochemistry of that system. Thus, it is critical to understand the biogeochemical response to changing $\mathrm{O}_{2}$ concentrations in that region.

In this study, we investigated differences in microbial community structure in an $\mathrm{O}_{2}$ depleted eddy, surrounding ETNA open waters, and upwelled waters on the Mauritanian shelf. This was achieved using a combined high-throughput $16 \mathrm{~S}$ rDNA amplicon sequencing/qPCR approach along with carbon uptake rate measurements and hydrochemical observations. This study aimed to understand the microbial community response to $\mathrm{O}_{2}$ depleted conditions with regard to primary production and remineralization in these poorlydescribed anomalies, to improve understanding of the sensitivity of the ETNA biogeochemistry to future ocean deoxygenation.

\section{Material and methods}

\subsection{Data collection}

Remotely sensed sea level anomalies (SLA), in combination with temperature and salinity data measured by Argo floats (an overview is presented by Schütte et al., 2015) were used for general eddy identification and tracking in this area. After identification of a low- $\mathrm{O}_{2}$ eddy candidate that was propagating towards CVOO, a pre-survey was started using autonomous gliders (see Karstensen et al., 2015b). Once the glider data had confirmed the low $\mathrm{O}_{2}$ concentration in the candidate eddy, a ship-based survey was started. First, we performed a survey with the Cape Verdean R/V Islandia on 6 March 2014 (samples from this survey are further referred to as eddy_1), followed by a second survey with the German R/V Meteor (cruise M105; 19 March 2014; samples from this survey are further referred to as eddy_2). Moreover, the background signal (i.e. waters outside the eddy) was measured, in order to compare the eddy with the typical open-ocean ETNA environment. For this purpose, we used metagenomic samples from the CVOO time series monitoring site (collected on 19 March 2014 during cruise M105). Samples from the Mauritanian shelf collected during R/V Meteor Cruise M107 (station $675,18.22^{\circ} \mathrm{N} / 16.56^{\circ} \mathrm{W}$, collected on 24 June 2014) represent data from the eddy formation area. Station 675 was chosen according to its location within the area that Schütte et al. (2015) identified as the region of eddy formation and further because of the observed low $\mathrm{O}_{2}$ concentrations of $33.9 \mu \mathrm{mol} \mathrm{kg} \mathrm{k}^{-1}$ at $115 \mathrm{~m}$ depth (which corresponds to a potential density of $\sigma_{T}=26.4 \mathrm{~kg} \mathrm{~m}^{-3}$, thus similar to the core density of minimal $\mathrm{O}_{2}$ concentrations in the eddy).

In addition to metagenomic sampling, carbon uptake measurements were performed during the R/V Meteor M105 survey at two stations: no. 186 (profile $10,19.3^{\circ} \mathrm{N}, 24.77^{\circ} \mathrm{W}$ ) and no. 190 (profile $15,18.67^{\circ} \mathrm{N}, 24.87^{\circ} \mathrm{W}$, see Fig. 1c, blue crosses).

\subsection{Water sampling and hydrographic parameters}

Discrete samples for salinity, dissolved $\mathrm{O}_{2}$ and nutrients on all surveys were taken from a CTD rosette equipped with Niskin-bottles. The CTD data were calibrated against salinity samples and CTD oxygen probe data (SBE 43 Clark electrode sensor) were calibrated against $\mathrm{O}_{2}$ concentrations, determined following the Winkler method using 50 or $100 \mathrm{~mL}$ samples. Salinity and nutrient concentrations were determined as described in Grasshoff et al. (1999). The CTD on R/V Meteor was equipped with double sensors for conductivity, temperature, and oxygen. Calibration followed standard procedures (GO-SHIP Manual; Hood et al., 2010).

\subsection{Oxygen respiration}

In order to estimate the net $\mathrm{O}_{2}$ consumption as a potential driver for microbiological community shifts a simple calculation was performed as follows:

$\Delta \mathrm{O}_{2}=\mathrm{O}_{2}(S)-\mathrm{O}_{2}(E)$,

where $\mathrm{O}_{2}(S)$ denotes the lowest $\mathrm{O}_{2}$ concentration detected on the shelf $\left(36.69 \pm 6.91 \mu \mathrm{mol} \mathrm{kg}^{-1}\right.$ at $\sigma_{T}=26.3 \pm 0.15 \mathrm{~kg} \mathrm{~m}^{-3}$, cruise M107, average of shelf stations between $18.10^{\circ} \mathrm{N} / 16.59^{\circ} \mathrm{W}$ and $18.25^{\circ} \mathrm{N} / 16.45^{\circ} \mathrm{W}$ ). This region was chosen as it was identified (Schütte et al., $2015)$ to be the area where the eddy most likely originated. $\mathrm{O}_{2}(E)$ denotes the lowest $\mathrm{O}_{2}$ concentration measured in the eddy core at the same potential density $\left(4.8 \mu \mathrm{mol} \mathrm{kg}{ }^{-1}\right.$ at $\sigma_{T}=26.35 \mathrm{~kg} \mathrm{~m}^{-3}$ during M105).

The daily $\mathrm{O}_{2}$ loss rate $\left(\Delta \mathrm{O}_{2 d}\right)$ was calculated as follows, assuming a lifetime of 180 days of the eddy (Schütte et al., 2015):

$\Delta \mathrm{O}_{2 d}=\Delta \mathrm{O}_{2} / 180$.

\subsection{Chlorophyll $a$ measurements}

Sea water samples $(0.5-1 \mathrm{~L})$ for chlorophyll $a(\mathrm{Chl} a)$ analyses were filtered ( $200 \mathrm{mbar}$ ) on $\mathrm{GF} / \mathrm{F}$ filters $(25 \mathrm{~mm}, 0.7 \mu \mathrm{m}$; Whatman, Maidstone, UK). Filters were transferred to a plastic vial and $1 \mathrm{~mL}$ of MilliQ water was added. Filters were immediately frozen at $-20^{\circ} \mathrm{C}$ and stored for at least $24 \mathrm{~h}$. Afterwards, $9 \mathrm{~mL}$ acetone $(100 \%)$ was added to the vials and 
the fluorescence was measured with a Turner Trilogy fluorometer (Sunnyvale, CA, USA). Calibration took place using a Chl $a$ standard dilution series (Anacystis nidulans, Walter CMP, Kiel, Germany). Chl $a$ concentrations were determined as described by Parsons et al. (1984).

\subsection{Molecular methods}

Seawater samples were taken from the Niskin-Bottles at selected CTD casts. For nucleic acid purification $2 \mathrm{~L}$ seawater was rapidly filtered (exact filtration volumes and times were recorded continuously) through $0.2 \mu \mathrm{m}$ polyethersulfone membrane filters (Millipore, Billerica, MA, USA). The filters were immediately frozen and stored at $-80^{\circ} \mathrm{C}$ until further analysis. Nucleic acids were purified using the Qiagen DNA/RNA AllPrep Kit (Qiagen, Hilden, Germany) with modifications as previously described (Löscher et al., 2012).

Extracts of DNA and RNA were quantified using a spectrophotometer (Thermo Fisher Scientific, Waltham, MA, USA). To remove DNA from RNA extracts, a DNase I treatment (Invitrogen, Carlsbad, CA) was performed; purity of RNA was checked by PCR amplification before random reverse transcription with the Quanti Tect ${ }^{\circledR}$ Reverse Transcription Kit (Qiagen, Hilden, Germany). HNLC, HLII and other Prochlorococcus ecotypes were qPCR-amplified using primers and PCR conditions as previously described (Ahlgren et al., 2006). Reactions were performed in technical duplicates in a final volume of $12.5 \mu \mathrm{L}$ using $0.25 \mu \mathrm{L}$ of each primer $\left(10 \mathrm{pmol}_{\mu} \mathrm{L}^{-1}\right), 3.25 \mu \mathrm{L}$ nuclease-free water and 6.25 $\mu \mathrm{L}$ SYBR qPCR Supermix W/ROX (Life Technologies, Carlsbad, CA, USA) on a ViiA7 qPCR machine (Life Technologies, Carlsbad, CA, USA) according to established protocols (Ahlgren et al., 2006; West et al., 2011). TaqMan-based qPCRs were performed for picophytoplankton (Prochlorococcus/Synechococcus) and bacteria as previously described (Suzuki et al., 2001) in a final volume of $12.5 \mu \mathrm{L}$ with primer/probe concentrations as shown elsewhere (Table 1, West et al., 2011), but with the addition of $0.5 \mu \mathrm{L}$ BSA $\left(20 \mathrm{mg} \mathrm{mL}^{-1}\right.$ ) and $6.25 \mu \mathrm{L}$ TaqMan Mix (Life Technologies, Carlsbad, CA, USA). Dilution series of plasmids containing the target gene were used as standards as described (Lam et al., 2007; Löscher et al., 2012). Nitrogen cycle key functional genes amoA, nirS, hzo and nifH were amplified and quantified from DNA and cDNA following established protocols (Lam et al., 2007; Langlois et al., 2008; Löscher et al., 2012, 2014). Detection limits of qPCR assays were determined from no-template controls, which were run in duplicate for each primer (and probe) set, and were undetectable after 45 cycles, thus setting the theoretical detection limit of our assay mixtures to one gene copy. However, detection limits additionally depend on the amount of filtered seawater per sample, elution volume after extraction, and the amount of sample loaded to the qPCR assay. Based on a filtration volume of $2 \mathrm{~L}$ seawater, a detection limit of 20 copies $\mathrm{L}^{-1}$ has been determined. qPCR efficiencies were calculated using the formula $E=10^{-1 / \text { slope }}-1$, and were between 95.3 and $96.8 \%$.

\subsubsection{PCR amplification of bacterial and archaeal 16S rDNA for Illumina MiSeq amplicon sequencing}

For the analysis of the bacterial community, hypervariable regions $\mathrm{V} 1$ and $\mathrm{V} 2$ of the $16 \mathrm{~S}$ rDNA was amplified from genomic DNA using the primer set 27 forward (Frank et al., 2007) and 338 reverse (Fierer et al., 2008). Beside the target-specific region the primer sequence contained a linker sequence, an 8-base barcode and the Illumina-specific region P5 (forward primer) or P7 (reverse primer), respectively, as recently described (Kozich et al. 2013). The PCR reaction mixture consisted of $13.6 \mu \mathrm{L}$ DEPC $\mathrm{H}_{2} \mathrm{O}$ (Roth, Karlsruhe, Germany), $0.4 \mu \mathrm{L}$ of $10 \mathrm{mM}$ dNTPs (Thermo Fisher Scientific), $4 \mu \mathrm{L} 5 \times$ HF-buffer (Thermo Fisher Scientific, Waltham, MA, USA), $0.8 \mu \mathrm{L}$ primers $(5 \mu \mathrm{M}$, Eurofins, Ebersberg, Germany), $0.2 \mu \mathrm{L}$ Phusion high-fidelity polymerase (2 $\mathrm{UL}^{-1}$, Thermo Fisher Scientific, Waltham, MA, USA) and $1 \mu \mathrm{L}$ genomic DNA with a concentration between 10

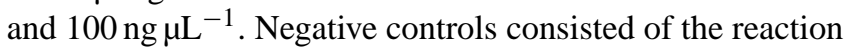
mixture as described above without the addition of DNA. PCR reaction conditions started with an initial denaturation step for $5 \mathrm{~min}$ at $95^{\circ} \mathrm{C}$ followed by 30 cycles of $15 \mathrm{~s}$ denaturation at $95^{\circ} \mathrm{C}, 30 \mathrm{~s}$ primer annealing at $52^{\circ} \mathrm{C}$ and $30 \mathrm{~s}$ elongation at $72^{\circ} \mathrm{C}$ and a final elongation at $72^{\circ} \mathrm{C}$ for $5 \mathrm{~min}$.

For analysis of the archaeal community, hypervariable regions V5-V7 of the 16S rDNA were amplified from genomic DNA using the primer set 787 forward and 1059 reverse (Yu et al., 2005) with 8-base barcode and Illumina specific adapters. Reaction mixture, PCR protocol and purification were identical to the amplification of bacterial community DNA amplification, the only difference was the annealing temperature $\left(58^{\circ} \mathrm{C}\right)$. Amplification was checked for correct size and band intensity on a $2.5 \%$ agarose gel. Amplicons were purified using the MinElute Gel Extraction Kit (Qiagen, Hildesheim, Germany) and quantified on a spectrophotometer (Nanodrop 1000, Thermo Fisher Scientific, Waltham, MA, USA). Pooled purified amplicons were prepared and sequenced according to the manufacturer's protocol on a MiSeq Instrument using the MiSeq reagent Kit V3 chemistry (Illumina, San Diego, CA, USA). Sequences were submitted to NCBI Sequence Read Archive under accession number PRJNA288724.

\subsubsection{Sequence analysis of 16S rDNA gene amplification}

Sequence processing was performed using mothur software version 1.32.1 (Kozich et al., 2013; Schloss et al., 2009). 4054723 bacterial sequence read pairs could be concatenated to contiguous sequences (contigs) using the command make.contig. Contigs containing ambiguous bases, ho- 
mopolymers longer than eight bases or contigs longer than 552 bases were deleted from the data set. Redundant sequences were clustered using the command unique.seqs, which led to 645444 unique sequences. Sequences were consecutively aligned with align.seqs against a modified version of the SILVA database release 102 (Pruesse et al., 2007) containing only the hypervariable regions V1 and V2. The alignment was optimized by removing sequences not aligning in the correct region with screen.seqs, and by the removal of gap-only columns using filter.seqs. The optimized alignment contained 636701 sequences of lengths between 255 and 412 bases. Rare sequences with up to three positional differences compared to larger sequence clusters were merged with the latter by the pre.cluster command. Chimeric sequences were removed with the implemented software UCHIME (Edgar et al., 2011) using the command chimera.uchime, followed by remove.seqs.

Taxonomic classification of the remaining sequences was done using the Wang approach based on a modified version of the Greengenes database (DeSantis et al., 2006) with a bootstrap threshold of $80 \%$. Sequences of archaea, chloroplasts and mitochondria were removed with remove.lineage. Operational taxonomic units (OTUs) were formed by average neighbor clustering using the cluster.split command, parallelizing the cluster procedure by splitting the data set at the taxonomic order level. A sample-by-OTU table was generated with make.shared at the $97 \%$ sequence similarity level. The resulting table contained 15509 OTUs. OTUs were classified taxonomically using the modified Greengenes database mentioned above and the command classify.otu.

Archaeal sequences showed lower quality in the reverse read, which lead to multiple ambiguous bases in the contigs formed. For this reason only the forward read starting from base 36 was used for analysis. Sequence analysis was performed as described above for bacterial $16 \mathrm{~S}$ sequences, except that the alignment (align.seqs) was accomplished using the SILVA archaeal reference release 102 (Pruesse et al., 2007) fitted for hypervariable regions V5-V7. Classification (classify.seqs and classify.otu) was conducted using the RDP database file release 10 (Cole et al., 2014; Wang et al., 2007). Results and additional information on the archaeal community structure are listed in the Supplement.

An overview of the sequencing output is given in Table S1 in the Supplement.

\subsection{Statistics}

Low-abundance OTUs were removed to reduce noise and computation time. Statistical downstream analysis was performed in R v3.1.3 (R Core Team, 2015) with custom scripts (available from the authors on request). As OTUs of very low abundance only increase computation time without contributing useful information, they were removed from the data set as follows: after transformation of counts in the sample-by-OTU table to relative abundances (based on the total number of reads per sample), OTUs were ordered by decreasing mean percentage across samples. The set of ordered OTUs for which the cumulative mean percentage amounted to $99 \%$ was retained in the filtered OTU table.

Distribution of OTUs across samples was modeled by a set of environmental variables (Table S2) with minimal interdependence. The variance in OTU composition (i.e., the extent of change in OTU abundance across samples) explained by the measured environmental variables was explored by redundancy analysis (RDA) with Hellinger-transformed OTU counts (Langfeldt et al., 2014; Stratil et al., 2013, 2014) using the R package vegan (Oksanen et al., 2013). In order to minimize collinearity of explanatory variables in the RDA model, a subset of the recorded environmental variables was chosen according to their variance inflation factor (VIF), employing vegan's functions $r d a$ and vif.cca. Starting with an RDA model that contained all explanatory variables, the variable with the highest VIF was iteratively determined and removed from the model until all remaining explanatory variables had a $\mathrm{VIF}<2.5$.

OTU distribution was subject to "Realm" depending on $\mathrm{O}_{2}$ concentration. Model selection started with a full RDA model containing all main effects and possible interactions based on the set of explanatory variables with minimal collinearity. This model was simplified by backward selection with function ordistep. The final RDA model exhibited a significant interaction effect "Realm: $\mathrm{O}_{2}$ " (see results section). For plotting and indicator analysis (see below), the continuous variable " $\mathrm{O}_{2}$ " was converted into a factor with two levels "high $\mathrm{O}_{2}$ " (>90 $\left.\mathrm{mol} \mathrm{L}^{-1}\right)$ and "low $\mathrm{O}_{2}$ " $(\leq 90 \mu \mathrm{mol} \mathrm{L}-1)$; the threshold of $90 \mu \mathrm{mol} \mathrm{L}^{-1}$ was chosen for two reasons: (1) to obtain sample groups of fairly equal size between stations, which include low $\mathrm{O}_{2}$ parts of the water column at all sampling stations in order to enable a comparison between the ETNA OMZ (outside the eddy) and the eddy OMZ. (2) $90 \mu \mathrm{mol} \mathrm{L}^{-1}$ has previously described the highest concentration of $\mathrm{O}_{2}$ at which denitrification has been detected to be active (Gao et al., 2010). The presence of nirS transcripts (see Sect. 3.4) indicated a potential importance for denitrifiers in the eddy, therefore the theoretical upper limit of $90 \mu \mathrm{mol} \mathrm{L}^{-1}$ was chosen.

We determined OTUs typical for a given combination of levels of factors "Realm" and " $\mathrm{O}_{2}$ ". OTUs significantly correlated with any axis in the final RDA model were determined using the function envfit with $10^{5}$ permutations, followed by Benjamini-Hochberg correction (false discovery rate, FDR) (Benjamini and Hochberg, 1995). In order to reduce the number of tests in this procedure, OTUs were prefiltered according to their vector lengths calculated from corresponding RDA scores (scaling 1) by profile likelihood selection (Zhu and Ghodsi, 2006).

OTUs significant at an FDR of $5 \%$ were further subject to indicator analysis with function multipatt of the R package indicspecies v1.7.4 (De Cáceres and Legendre, 2009) with $10^{5}$ permutations. Indicator OTUs - in analogy to indicator 
species sensu De Cáceres and Legendre (2009) - are OTUs that prevail in a certain sample group (here: a level of factor "Realm" within a chosen $\mathrm{O}_{2}$ level) while being found only irregularly and at low abundance in other sample groups. In order to remove the effects of the covariate "Depth" in indicator analysis, Hellinger-transformed counts of significant OTUs were first subjected to a linear regression with "Depth"; residuals of this regression were then transformed to positive values by subtraction of their minimum and used as input for indicator analysis.

3-D visualizations of the RDA model were produced in kinemage format (Richardson and Richardson, 1992) using the $\mathrm{R}$ package R2Kinemage developed by S.C.N., and displayed in KiNG v2.21 (Chen et al., 2009).

Diversity within samples was related to environmental variables by advanced linear regression. For alpha diversity analysis, effective OTU richness (Shannon numbers equivalent, ${ }^{1}$ D, Jost, 2006, 2007) was calculated from the filtered OTU table. ${ }^{1} \mathrm{D}$ was fitted to the set of explanatory variables with minimal collinearity in a generalized least squares (GLS) model using function $g l s$ of the R package nlme v3.1120 (Pinheiro et al., 2015). The variable "NO2" was square root-transformed to decrease the potential leverage effect of its two highest values $\left(0.25\right.$ and $0.28 \mu \mathrm{mol} \mathrm{L}^{-1}$, respectively) on ${ }^{1} \mathrm{D}$. Apart from main effect terms, the interaction term "Realm: $\mathrm{O}_{2}$ " was included into the GLS model for comparability with beta diversity analysis (see results section). The variance structure of the GLS model was chosen to account for both different variances per level of "Realm" and an overall decreasing variance by "Depth". The resulting model was validated following the recommendations of Zuur et al. (2009). While only the "Realm" effect was significant, the other terms were kept in the model to maintain a valid residual distribution. For visualization of the (partial) effect of only factor "Realm" on ${ }^{1} \mathrm{D}$, partial response residuals were extracted from the full GLS model re-fitted without the "Realm" main effect. These partial response residuals were then modelled by the "Realm" main effect alone, using the same variance structure as for the full GLS model.

\subsection{Carbon fixation rate measurements}

Seawater incubations were performed in triplicate at two stations, one inside the eddy (station 10, M105 cruise) and one in ETNA open waters (station 15, M105 cruise, both stations indicated in Fig. 1c). Seawater was sampled from a CTD system and directly filled into $2.8 \mathrm{~L}$ polycarbonate bottles (Nalgene, Thermo Fisher Scientific, Waltham, MA, USA). For carbon fixation measurements, $\mathrm{NaH}^{13} \mathrm{CO}_{3}$ (Cambridge Isotope Laboratories, MA, USA) was dissolved in sterile deionized water $\left(>18.2 \mathrm{M} \Omega \mathrm{cm}^{-1}\right.$, MilliQ, MerckMillipore, Darmstadt, Germany; $5 \mathrm{~g} / 294 \mathrm{~mL}$ ). A volume of $1 \mathrm{~mL}(2.8 \mathrm{~L}$ bottles) was added to the incubations with a syringe $(\sim 4.4$ at $\%$ final). After amendment, bottles were stored on deck in a seawater-cooled Plexiglas incubator covered with light foils (blue-lagoon, Lee filters, Andover, Hampshire, UK) that mimic light intensities at corresponding sampling depths $(5 / 10 / 30 / 70 \mathrm{~m})$. Samples from below the euphotic zone were stored at $12{ }^{\circ} \mathrm{C}$ in the dark. The depth of the euphotic zone was estimated from photosynthetically active radiation (PAR) sensor measurements from CTD profiles as the depth where PAR is $<1 \%$ of the surface value. This corresponded to $60 \mathrm{~m}$ water depth during this survey. After $24 \mathrm{~h}$ of incubation, $1.5-2.8 \mathrm{~L}$ of seawater was filtered onto precombusted $\left(450^{\circ} \mathrm{C}, 5 \mathrm{~h}\right) 25 \mathrm{~mm}$ diameter $\mathrm{GF} / \mathrm{F}$ filters (Whatman, Maidstone, UK) under gentle vacuum $(-200 \mathrm{mbar})$. Filtrations were stopped after $1 \mathrm{~h}$ since high particle load of surface water led to a clogging of the filters. Filters were oven dried $\left(50^{\circ} \mathrm{C}\right)$ for $24 \mathrm{~h}$ and stored over desiccant until analysis. Environmental samples of $2.8 \mathrm{~L}$ untreated seawater were filtered and prepared in the same way to serve as blank values. For isotope analysis, GF/F filters were acidified over fuming $\mathrm{HCl}$ overnight in a desiccator. Filters were then ovendried for $2 \mathrm{~h}$ at $50^{\circ} \mathrm{C}$ and pelletized in tin cups. Samples were analyzed for particulate organic carbon and nitrogen (POC and $\mathrm{PON}$ ) and isotopic composition using a $\mathrm{CHN}$ analyzer coupled to an isotope ratio mass spectrometer.

\section{Results and discussion}

\subsection{Hydrography of low- $\mathrm{O}_{2}$ eddy reveals similarities to shelf waters}

As the detailed properties of the investigated eddy are described in Schütte et al. (2015) only the main characteristics are mentioned here.

The surveyed low- $\mathrm{O}_{2}$ eddy belongs to the group of the anticyclonic modewater eddies (ACME) (Karstensen et al. 2015a). It has been reported that ACME promote intense primary production in surface and mixed layer waters (Mahadevan, 2014) fueled by nutrient supply to the euphotic zone. The surveyed eddy had a diameter of about $100 \mathrm{~km}$ and was characterized by highly elevated mixed-layer chlorophyll a (chl a) concentrations, a positive SLA signature (Fig. 1) and a low $\mathrm{O}_{2} /$ low-salinity core (Fig. 2). The $\mathrm{O}_{2}$-depleted core, with concentrations of less than $5 \mu \mathrm{mol} \mathrm{kg}{ }^{-1}$, was centered rather deep for an ACME at $\sim 100 \mathrm{~m}$ depth. Concentrations of less than $30 \mu \mathrm{mol} \mathrm{kg}{ }^{-1}$ were observed in the eddy water column between 70 to $150 \mathrm{~m}$ depth (Figs. 2, 3a), which is significantly below average $\mathrm{O}_{2}$ concentrations in that region. $\mathrm{O}_{2}$ concentrations in the core decreased over the survey period (March 2014), (see Fiedler et al. (2015), for a detailed description of $\mathrm{O}_{2}$ properties). During the metagenomic sampling of the background signal ("no eddy") on the shelf (Meteor M107 cruise station $675,18.22^{\circ} \mathrm{N} / 16.56^{\circ} \mathrm{W}$, Fig. 1$), \mathrm{O}_{2}$ concentrations of $33.9 \mu \mathrm{mol} \mathrm{kg}{ }^{-1}$ were observed at $115 \mathrm{~m}$ depth, which corresponds to the potential density layer of the low $\mathrm{O}_{2}$ core in the eddy. The open-ocean background minimum $\mathrm{O}_{2}$ concentrations of about $70 \mu \mathrm{mol} \mathrm{kg} \mathrm{kg}^{-1}$ were detected 


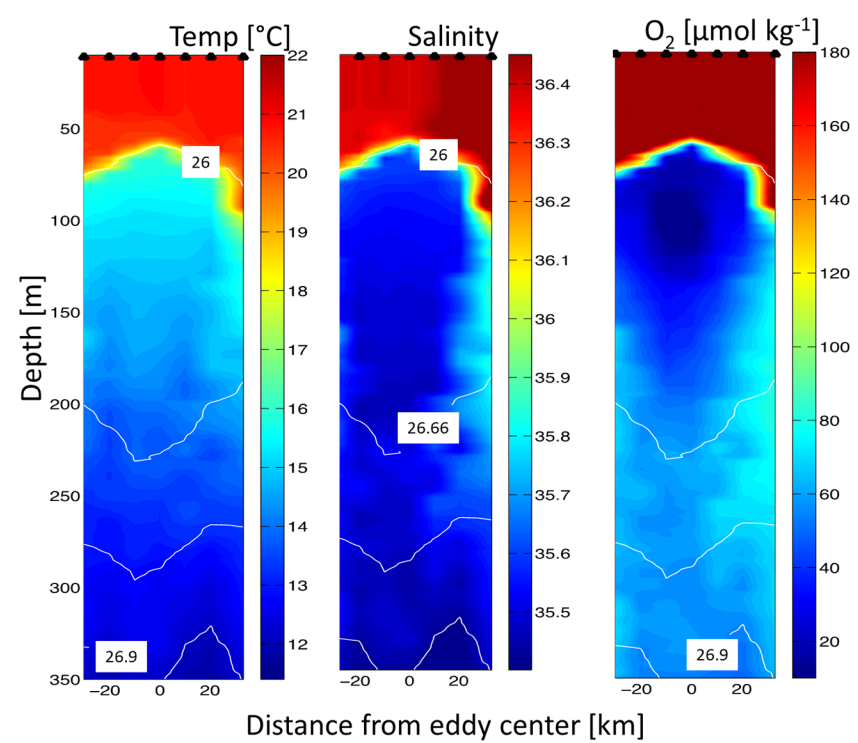

Figure 2. Temperature (left panel), salinity (middle panel) and $\mathrm{O}_{2}$ concentration (right panel) measured during a section of $\mathrm{R} / \mathrm{V}$ Meteor Cruise M105 across the studied eddy. Minimum $\mathrm{O}_{2}$ was $4.8 \mu \mathrm{mol} \mathrm{kg}^{-1}$ at $\sim 100 \mathrm{~m}$ water depth on that section; however, even lower $\mathrm{O}_{2}$ was detected with a glider $\left(1.2 \mu \mathrm{mol} \mathrm{kg}^{-1}\right)$. Isopycnals are indicated by white lines.

at $\sim 250 \mathrm{~m}$ depth at CVOO (Fig. 1). This can be considered average $\mathrm{O}_{2}$ concentrations for the open ETNA (Karstensen et al., 2008).

In the low- $\mathrm{O}_{2}$ eddy core, we observed nitrate and phosphate concentrations around twice as high as background concentrations at CVOO at the same depth (Fig. 3). However, $\mathrm{N}: \mathrm{P}$ ratios below the mixed layer were close to Redfield stoichiometry $(16.15 \pm 0.63$, Fig. 3$)$ and thus comparable to surrounding waters. Nitrate concentrations in the $\mathrm{O}_{2}$ min core $(\sim 100 \mathrm{~m}$ depth$)$ were similar to concentrations on the Mauritanian shelf at $100 \mathrm{~m}$ depth (Fig. 3) and most likely generated by very efficient local remineralization of nitrate from the sinking material (Karstensen et al. 2015b).

\subsection{Loss of phylogenetic diversity in low- $\mathrm{O}_{2}$ eddy waters}

A critical issue regarding climate change induced pressures on ocean ecosystems is to understand the effects of ocean acidification and deoxygenation on microbial communities as major drivers of the ocean's biogeochemistry (Riebesell and Gattuso, 2015). Thus, we investigated phylogenetic diversity of the microbial community with a $16 \mathrm{~S}$ rDNA amplicon sequencing approach of bacteria and archaea inside and outside the eddy.

Although the bacterial community was dominated by Proteobacteria in all samples, there were distinct differences between the community structures inside compared to outside the eddy (Fig. 4). Increased abundances of the uncultivated
SUP05 clade (up to $20 \%$ of proteobacterial sequences) have been recovered from eddy samples compared to surrounding waters (Supplement Fig. S1, Table S3). This clade is known to occur frequently in $\mathrm{O}_{2}$ depleted environments (Swan et al., 2011). Phyla such as Bacteroidetes, Actinobacteria and Firmicutes were only present in the eddy and increased in relative abundance over time. Those phyla were also detected in potential source waters on the shelf (Supplement Fig. S2). Interestingly, the family of Pelagibacteraceae, which belong to the ubiquitous SAR11 clade (Giovannoni et al., 1990), were strongly decreased in the eddy (to $\sim 1 \%$ of all reads), compared to CVOO samples ( $\sim 65 \%$ of all reads). SAR 11 was previously described as being sensitive to decreasing $\mathrm{O}_{2}$ concentrations (Forth et al., 2014), which may explain the absence of this classically highly abundant group from the eddy. In addition to the dissimilarity in bacterial diversity, we also detected a substantial difference in archaeal community composition between eddy stations and CVOO (Fig. S3). This was most obvious in samples from the eddy_2 station, where Methanomicrobia dominated the archaeal community in the $\mathrm{O}_{2}$-depleted parts of the water column but was absent in CVOO samples. The presence of methanogens in the low$\mathrm{O}_{2}$ eddy core samples may indicate potential for methanogenesis. Although the eddy has not been shown to become fully anoxic, methanogenesis tolerates $\mathrm{O}_{2}$ concentrations at low ranges (Angel et al., 2011).

Redundancy analysis (RDA) confirmed that the distribution of bacterial OTUs strongly differed between the two eddy stations and CVOO samples (Fig. 6a; RDA model: $\left.F_{6,24}=4.48, p<0.001\right)$. Changes in OTU composition mirrored the depth gradient (RDA "Depth": $F_{1,24}=2.08$, $p \approx 0.03$; Fig. 5) and were thus strongly correlated to chemical $\left(\mathrm{PO}_{4}^{3-}, \mathrm{NO}_{3}^{-}, \mathrm{SiO}_{2}\right)$ and physical $(T, S)$ properties (Fig. S4). The RDA model indicates a noticeable interaction effect of habitat ("Realm") and $\mathrm{O}_{2}$ concentration (RDA "Realm: $\mathrm{O}_{2} ": F_{2,24}=2.03, p \approx 0.02$ ), meaning that the "Realm" effect on bacterial community structure depends on the $\mathrm{O}_{2}$ level and vice versa. An overview of the parameters included in the RDA model is given in Table $\mathrm{S} 2 . \mathrm{O}_{2}$ and nutrient availability can thus be considered the major determining variables for the composition of the microbial community.

Our results further show a significant decrease in bacterial alpha diversity in the eddy relative to CVOO (Fig. 6). The community in eddy_2 samples was also markedly less diverse compared to those of the other realms (Fig. 6; generalized least squares (GLS) model: $F_{7,23}=5.37, p=0.001$; GLS "Realm": $\left.F_{2,23}=16.26, p<0.0001\right)$. This may be attributed to an aging effect of the eddy, and corresponds to progressive $\mathrm{O}_{2}$ loss and consecutive changes in the eddy biogeochemistry. We calculated an overall $\mathrm{O}_{2}$ loss of $0.18 \mu \mathrm{mol} \mathrm{kg} \mathrm{k}^{-1} \mathrm{~d}^{-1}$ at $100 \mathrm{~m}$ depth by respiration, when comparing the eddy core water to the potential origin waters on the shelf, assuming a lifetime of 180 days for the eddy (average $\mathrm{O}_{2}$ concentrations on the shelf from Meteor 
(a)

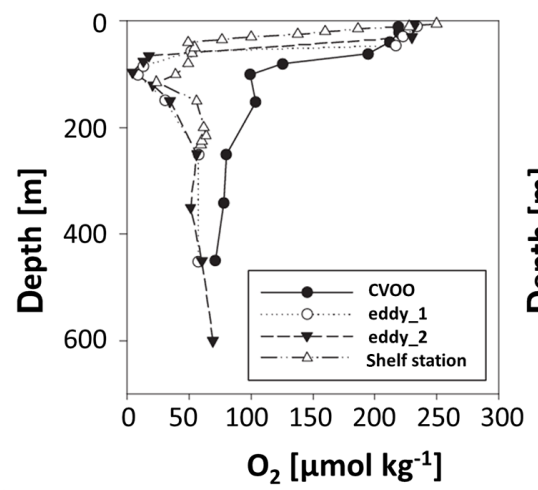

(b)

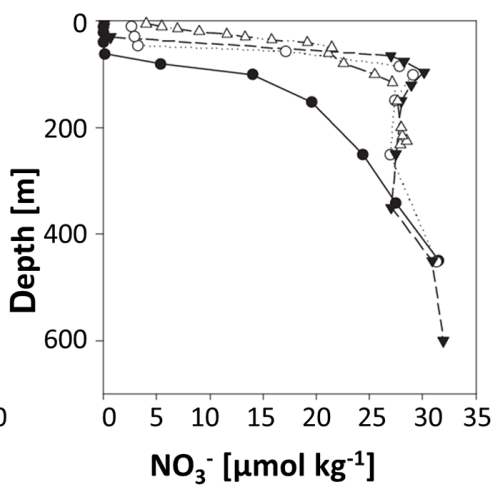

(c)

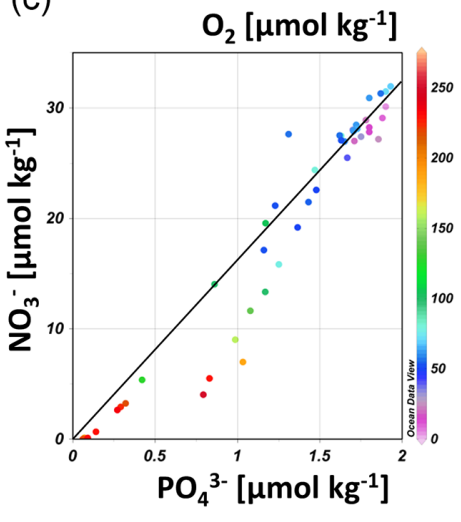

Figure 3. (a) $\mathrm{O}_{2}$ and (b) nitrate and (c) nitrite concentrations measured at the open-ocean station CVOO (black circles), in the first observation (eddy_1, open circles), second observation (eddy_2, black triangles) and on the Mauritanian shelf (open triangles). (d) Nitrate vs. phosphate concentration at the four sampling stations. The color code denotes the $\mathrm{O}_{2}$ concentration and the black line indicates the Redfield ratio of $\mathrm{N}: \mathrm{P}=16: 1$.

(a)

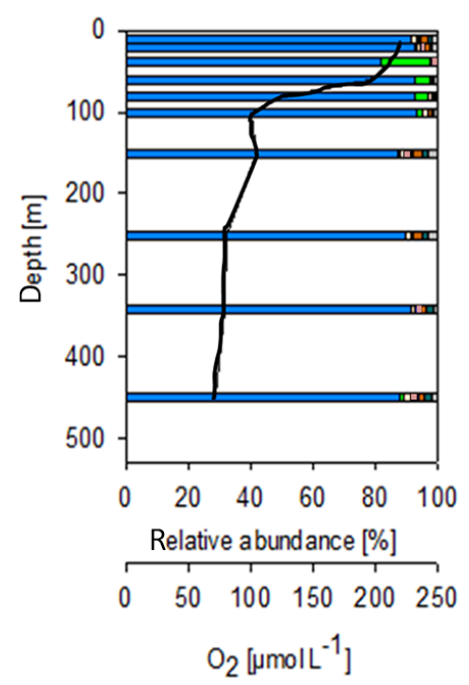

(b)

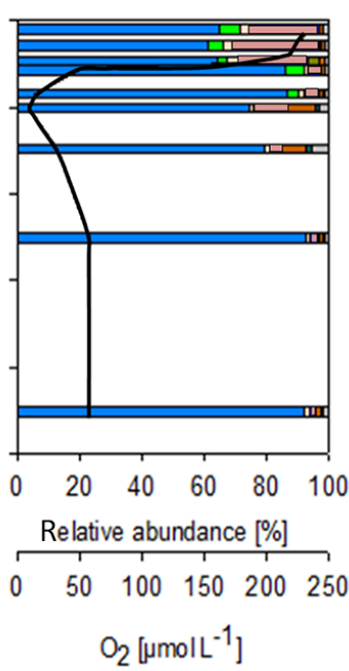

(c)

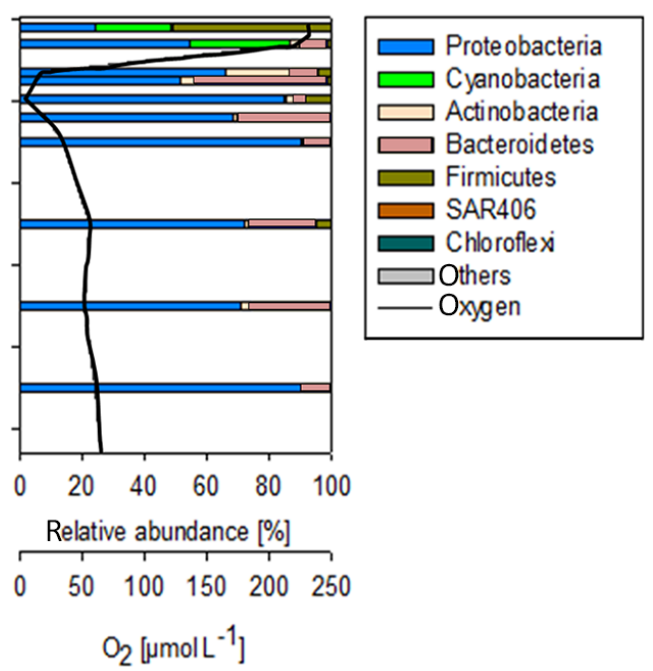

Figure 4. Distribution of bacterial phyla along vertical profiles of (a) CVOO, (b) first observation (eddy_1) and (c) second observation (eddy_2) is shown along with the $\mathrm{O}_{2}$ gradient (black line). Data sets result from 16S rDNA amplicon sequencing (an overview on archaeal sequence distribution is given in the Supplement).

M107 were $36.69 \pm 6.91 \mu \mathrm{mol} \mathrm{kg}{ }^{-1}$ compared to observed minimum $\mathrm{O}_{2}$ concentrations of $4.8 \mu \mathrm{mol} \mathrm{kg}{ }^{-1}$ in the eddy core). These results are comparable to previous estimates on low $\mathrm{O}_{2}$-eddies in that region (Karstensen et al., 2015a). Likewise, Fiedler et al. (2015) also observed a significant increase in $p \mathrm{CO}_{2}$ and dissolved inorganic carbon compared to coastal waters, indicating enhanced remineralization and respiration. Although our data set does not allow differentiation between high- $p \mathrm{CO}_{2}$ and low- $\mathrm{O}_{2}$ effects on the microbial community, it supports the view of a general loss in diversity. This may be attributed to a direct or indirect response to factors related to deoxygenation and increasing $p \mathrm{CO}_{2}$, such as the impact on nutrient stoichiometry, as previously suggested (Bryant et al., 2012).

Hence, climate change-related ocean deoxygenation and consequent shifts in nutrient stoichiometry may mean an overall loss of microbial diversity, with potential for substantial loss in the spectrum of metabolic functions in the future ocean.

\subsection{Specific Prochlorococcus clade contributes to primary production in the eddy}

The detected ACME was characterized by shoaling of the mixed layer depth in the center of the eddy. This coin- 

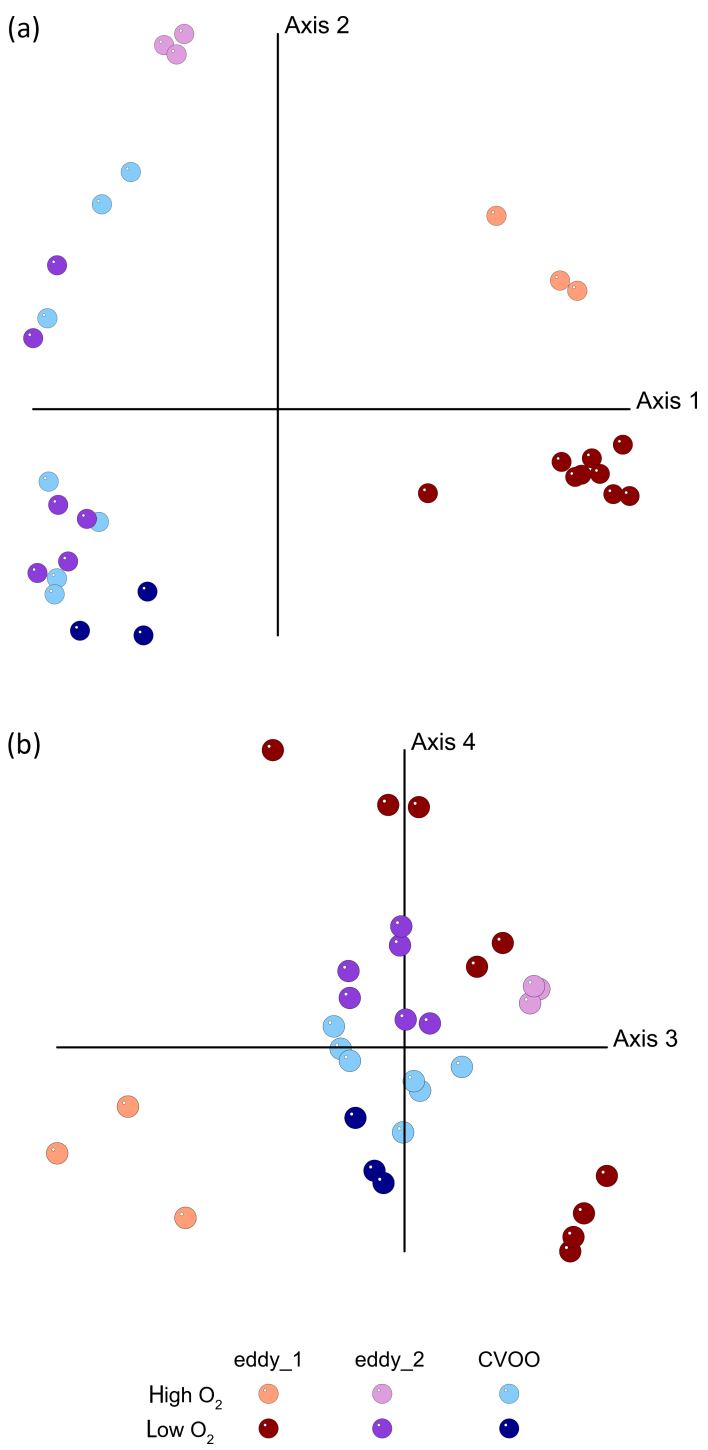

Figure 5. Redundancy analysis (RDA) of OTU distribution in samples from the first eddy observation (eddy_1), from the second eddy observation (eddy_2) and from CVOO based on 16S rDNA sequences. (a) First and second axis, (b) third and fourth axis of the RDA model, illustrating the interaction effect of factor "Realm" and $\mathrm{O}_{2}$ concentration. For plotting, the continuous variable " $\mathrm{O}_{2}$ " was converted into a factor with two levels "high $\mathrm{O}_{2}$ " $(>90 \mu \mathrm{M})$ and "low $\mathrm{O}_{2}$ " $(\leq 90 \mu \mathrm{M})$.

cided with a pronounced surface chl $a$ maximum as observed by ocean color based and remotely sensed chl $a$ estimates (Figs. 1a, 7), which was slightly deeper $(\sim 50$ $70 \mathrm{~m}$ water depth) outside the eddy. In accordance with increased chl $a$ concentrations, enhanced carbon uptake was observed via direct rate measurements of $\mathrm{H}^{13} \mathrm{CO}_{3}^{-}$uptake which was potentially fueled by increased nutrient availability from intermediate depths. We found a 3 -fold increase in depth-integrated carbon uptake rate in the $\operatorname{chl} a$ maximum of

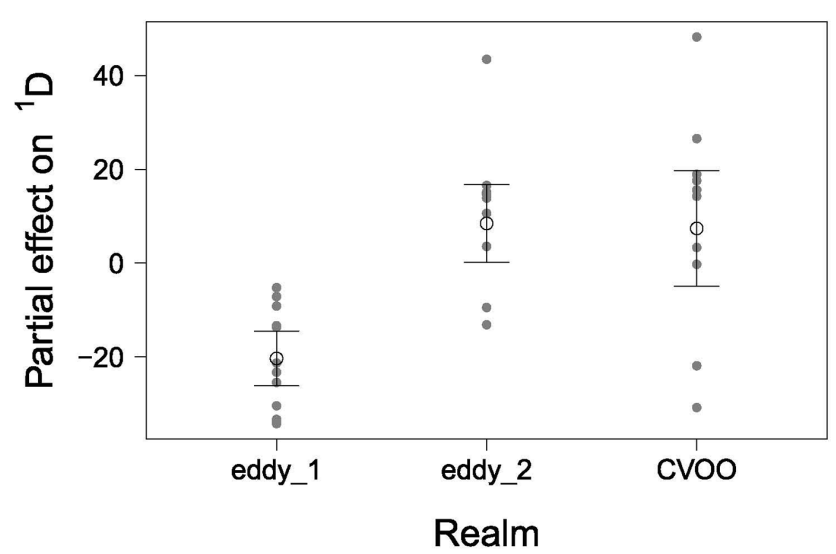

Figure 6. Alpha diversity analysis of eddy sampling stations (first observation (eddy_1), second observation (eddy_2)) and CVOO expressed as Shannon numbers equivalent $\left({ }^{1} \mathrm{D}\right)$. A strong and significant decrease in diversity is observed in the eddy. Partial response residuals (black symbols) were extracted from full GLS model refitted without the "Realm" main effect. Predicted values for partial residuals modelled by the "Realm" main effect alone (and thus adjusted for differences in $\mathrm{O}_{2}$ concentration) are shown as blue symbols. Error bars represent $95 \%$ confidence interval for fitted values.

the eddy $\left(178.3 \pm 30.8 \mathrm{~m} \mathrm{~mol} \mathrm{C} \mathrm{m}^{-2} \mathrm{~d}^{-1}\right)$ compared to surrounding waters $\left(59.4 \pm 1.2 \mathrm{mmol} \mathrm{C} \mathrm{m}^{-2} \mathrm{~d}^{-1}\right)$.

While the upper chl $a$ maximum in the eddy may likely be ascribed to eukaryotic primary producers such as diatoms and flagellates that are widely distributed and abundant in that region (Franz et al., 2012), confirmed by increased abundances of plastids in surface samples of our amplicon data set (Table S3). A secondary chl $a$ maximum dominated by cyanobacteria was detected in the eddy at about $100 \mathrm{~m}$ water depth, coinciding with the $\mathrm{O}_{2}$ minimum.

The quantitative analysis of cyanobacterial primary producers by $16 \mathrm{~S}$ rDNA-qPCR further revealed dominance of a specific clade of Prochlorococcus in the secondary chl $a$ maximum (Fig. S5 depicts phylogenetic relations of detected Prochlorococcus clades). This ecotype has so far not been identified in the ETNA and is only known from high nutrient low-chlorophyll (HNLC) regions of the eastern tropical Pacific Ocean (West et al., 2011). Its described adaptation to high nutrient conditions such as those present in this $\mathrm{O}_{2}$-depleted ACME points towards a selective advantage for this clade. Gene abundance of this ecotype - for convenience further referred to as HNLC-PCC (results of an ecotypespecific16S rDNA based qPCR) - showed a strong correlation with chlorophyll $\left(R^{2}=0.95, n=22\right)$ below the euphotic zone within the eddy. This correlation was not present outside the eddy, where HNLC-PCC abundance was approximately one third compared to the second eddy observation (Fig. 8). The Prochlorococcus community in surrounding waters was, however, dominated by another high-light ecotype of Prochlorococcus (further referred to as HL-PCC 
(a)

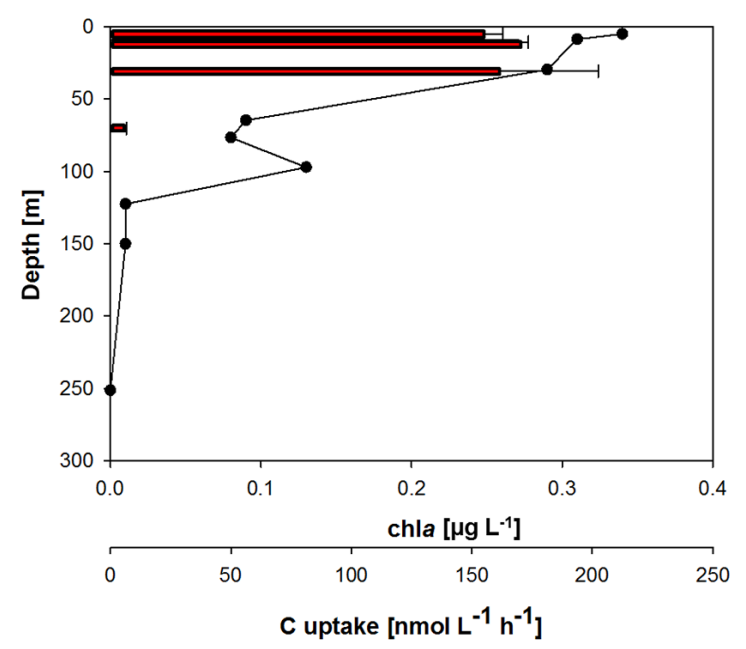

(b)

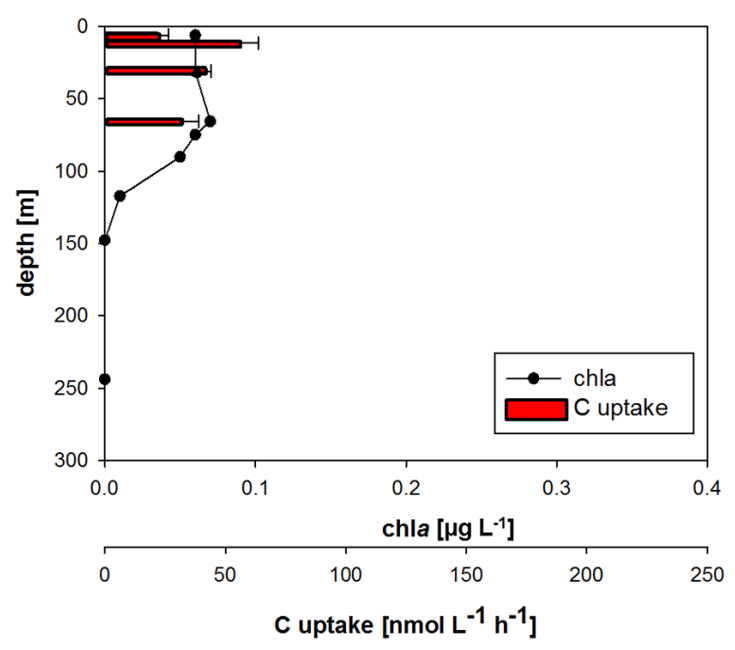

Figure 7. Chlorophyll $a$ ( $\mathrm{chl} a, \mu \mathrm{g} \mathrm{L}^{-1}$ ) distribution as determined from discrete measurements and carbon uptake rates (a) inside the eddy (eddy_2, second observation) and (b) at the eddy rim (location denoted in Fig. 1). Error bars indicate the standard deviation of three replicate samples for C uptake.

(West et al., 2011)). Contrary to HNLC-PCC, HL-PCC was not detected inside the eddy. The difference between the CVOO, eddy_1 and eddy_2 observations points towards a community shift of Prochlorococcus related clades depending on specific characteristics of the eddy $\left(\mathrm{O}_{2}\right.$, nutrient availability) with the potential to alter primary productivity in that region. Under increasing $p \mathrm{CO}_{2}$ levels, Prochlorococcus is predicted to substantially increase in abundance (Flombaum et al., 2013). Elevated $p \mathrm{CO}_{2}$ levels in the eddy core water may therefore - apart from favorable elevated nutrient concentrations - explain the additional selective advantage of specific Prochlorococcus clades, in this case of HNLCPCC. This may be critical as Prochlorococcus is one of the most abundant photosynthetic organisms in the ocean and contributes to $\sim 40 \%$ of dissolved organic carbon supporting bacterial production (Bertillson et al., 2005).

Besides a direct impact of $\mathrm{O}_{2}$, nutrients and $p \mathrm{CO}_{2}$, increased abundances of Prochlorococcus in the eddy may be explained from an interaction effect in the microbial community present in the eddy. Prochlorococcus is supposed to play a major role in sustaining heterotrophs with organic carbon compounds such as glycine and serine, thus favoring their growth (Biller et al., 2015; Carini et al., 2013). Conversely, Prochlorococcus benefits from the presence of heterotrophs as they diminish the concentration of reactive oxygen species in their immediate surroundings, which is not feasible for Prochlorococcus due to the lack of catalase and peroxidase genes (Berube et al., 2014; Morris et al., 2008). The close proximity of increased abundances of the HNLC-PCC maximum to the $\mathrm{O}_{2}$ minimum in the eddy may thus point towards a beneficial relationship between the HNLC-PCC and the heterotroph-dominated, eddy core water microbial community.

\subsection{Increased primary productivity promotes a specific heterotrophic microbial community in underlying waters}

We analyzed species indicative for the eddy and CVOO for either high- $\mathrm{O}_{2}$ conditions $\left(>90 \mu \mathrm{mol} \mathrm{kg}{ }^{-1}\right.$ ) or low- $\mathrm{O}_{2}$ conditions $\left(\leq 90 \mu \mathrm{mol} \mathrm{kg}^{-1}\right)$. Indicator OTUs for high $\mathrm{O}_{2}$ in the eddy were mostly associated with different clades of Proteobacteria, whereas Pelagibacteraceae dominated at CVOO in accordance with several studies describing those organisms as ubiquitous in open-ocean oxic waters (Morris et al., 2002; Rappé et al., 2002; Poretsky et al., 2009; DeLong, 2009; Brown et al., 2014). High-O ${ }_{2}$ samples of all three sampling stations were dominated - as most parts of the ocean - by indicator OTUs belonging to the Proteobacteria. The Prochlorococcus clade HNLC-PCC targeted by qPCR could be recovered in the 16S rDNA amplicon sequences, as well.

For low- $\mathrm{O}_{2}$ conditions, indicator species present in the eddy were mostly affiliated to the Cytophaga-FlavobacteriaBacteroides (CFB) group (Glöckner et al., 1999) (Table S4). Members of Bacteroidetes and Proteobacteria (Gramella, Leeuwenhoekiella marinoflava, unclassified Comamonadaceae species) were found to be indicative for the low- $\mathrm{O}_{2}$ realm. Gramella-like organisms are usually a quantitatively important fraction of the heterotrophic marine bacterioplankton, often attached to marine snow but also found free-living in nutrient-rich microenvironments (Buchan et al., 2014). Frequently associated with extensive phytoplankton blooms (Buchan et al., 2014), their ability to degrade high 
A

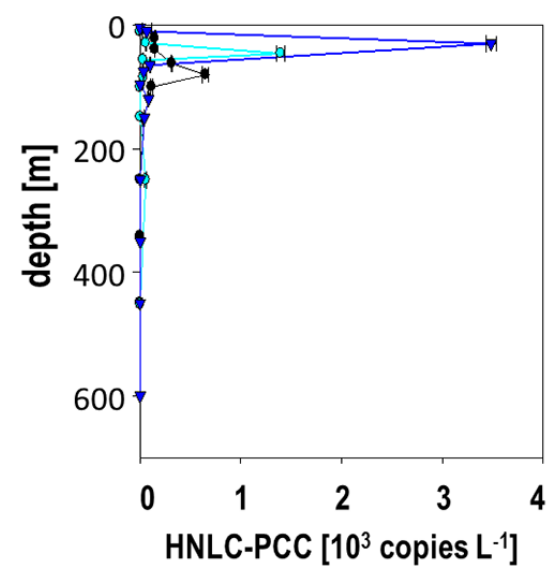

B

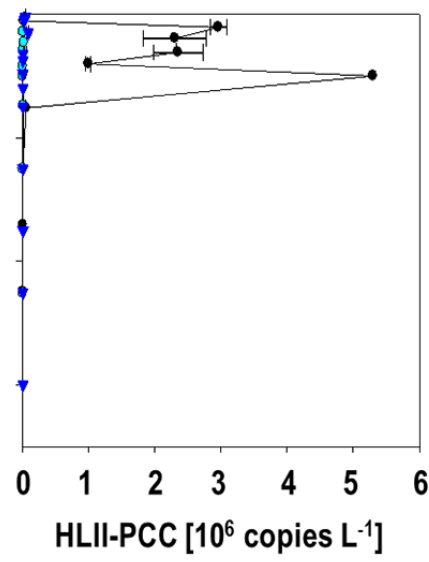

C

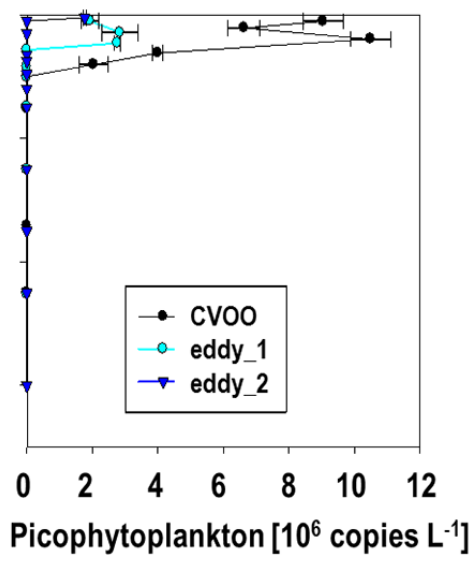

Figure 8. Vertical distribution of Prochlorococcus and Synechococcus ecotypes quantified by qPCR. While the HNLC-PCC (a) dominates the eddy water mass and increases from the first observation (eddy_1) to the second observation (eddy_2) it is nearly absent outside the eddy (CVOO). HLII-PCC (b) occurs in highest abundances outside the eddy, while being close to the detection limit inside the eddy. (c) shows the distribution of pico-phytoplankton as detected with a general primer-probe system (Suzuki et al., 2001).

molecular weight compounds in both the dissolved and particulate fraction of the marine organic matter pool points towards a specific role in respiration processes and the marine C cycle (as described for "Gramella forsetii" KT0803, Bauer et al. (2006). Karstensen et al. (2015a) described a particle maximum associated to the low- $\mathrm{O}_{2}$ core of those eddies which likely harbors this specific heterotrophic community. Further, in the core of the ACME presented here, the integrated abundance (upper $600 \mathrm{~m}$ ) of large aggregates was five times higher than in surrounding waters (Hauss et al., 2015).

Enhanced productivity and consecutive respiration and $\mathrm{O}_{2}$ decrease may enable $\mathrm{N}$ loss processes to occur in the open ETNA, which have previously not been described for the ETNA waters (Löscher et al., 2012, 2015; Ryabenko et al., 2012). qPCR results of key gene distribution ( $a m o A$ for nitrification as sum of bacterial and archaeal nitrifiers, nirS as key gene for denitrification) in that area show a decrease of amoA in the eddy, while nirS shows higher abundances inside the eddy with $\sim 3000$ copies $\mathrm{L}^{-1}$ at depth of the $\mathrm{O}_{2}$ minimum (compared to $\sim 100$ copies $\mathrm{L}^{-1}$ outside the eddy). Besides a direct sensitivity of nitrifiers to anoxic conditions, the decrease in amoA gene abundance (determined by qPCR) towards the $\mathrm{O}_{2}$ minimum in the eddy may result from an effect of elevated $p \mathrm{CO}_{2}$ (see Fiedler et al., 2015) and the corresponding drop in $\mathrm{pH}$ on ammonia due to a shift in the ammonia/ammonium equilibrium. The latter has previously been described to alter the efficiency of nitrification (Beman et al., 2011). Further, nirs transcripts as quantified by qPCR were

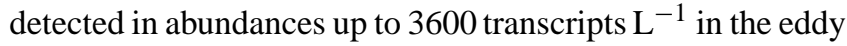
$\mathrm{O}_{2}$ minimum, while no transcripts were detected outside the eddy (Fig. 9).

The presence and expression of nirS supports the view that potential for $\mathrm{N}$ loss is also present in the usually oxic open ETNA. This is in line with another study on nitrous oxide $\left(\mathrm{N}_{2} \mathrm{O}\right)$ production from the same eddy (Grundle et al., 2015), where the authors observed massively increased $\mathrm{N}_{2} \mathrm{O}$ concentrations in the oxygen deficient eddy core waters in connection with denitrification. Observations from e.g. the eastern tropical Pacific Ocean demonstrated previously that mesoscale eddies are drifting hotspots of $\mathrm{N}$ loss (Altabet et al., 2012). This might be explained by feedback mechanisms between eutrophication, enhanced primary productivity and consecutive enhanced export production, which may promote denitrification in those systems as suggested by Kalvelage et al. (2013). Our results strongly suggest that $\mathrm{N}$ loss is possible in eddy systems of that region, thus altering one major biogeochemical cycle with unknown consequences for the ETNA biogeochemistry.

In case of the described eddy, we neither detected key genes for anammox ( $h z o$, Schmid et al., 2008) nor significant abundances of the key genes for dinitrogen fixation. The latter has been investigated by screening for the functional key gene, nifH, which has been tested for classical diazotrophs as Trichodesmium, UCYN-A, UCYN-B, UCYN-C, gamma proteobacterial diazotrophs and DDAs; all of which were not quantifiable by qPCR. This may be explained by the high availability of inorganic $\mathrm{N}$ sources, as well as the prevalence of $\mathrm{N}: \mathrm{P}$ close to the Redfield ratio of $16: 1$ as mentioned above.

Although $\mathrm{N}_{2}$ fixation does not appear to play a role in the low-oxic core waters or adjacent surface waters of the eddy, it may occur as a result of increasing $\mathrm{N}$ loss and resulting excess $\mathrm{P}$ as previously discussed for other $\mathrm{O}_{2}$ depleted marine habitats (Deutsch et al., 2007; Fernandez et al., 2011; Löscher et al., 2014; Ulloa et al., 2012). 
(a)

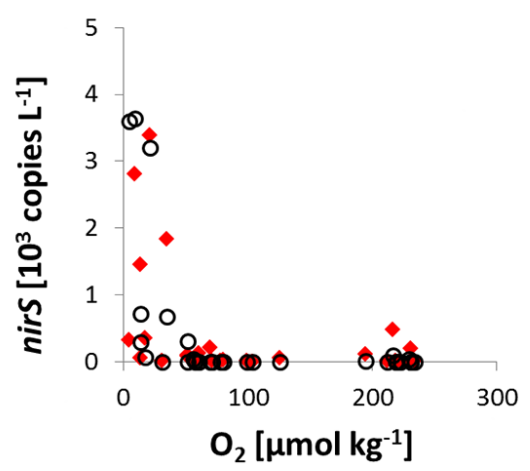

(b)

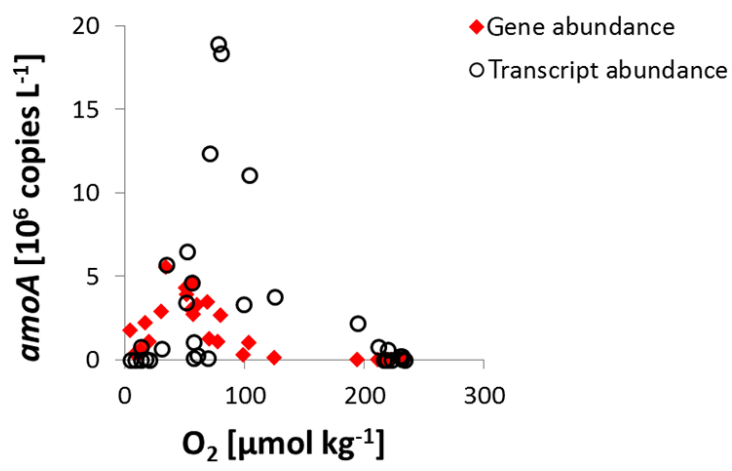

Figure 9. Gene and transcript abundance vs. $\mathrm{O}_{2}$ concentrations of samples from the eddy observations (eddy_1 and eddy_2) and CVOO. (a) shows the key gene for denitrification, nirS, coding for the nitrite reductase, (b) shows archaeal amoA as key functional gene of ammonia oxidation, coding for the ammonia monooxygenase. Gene abundances are denoted in red, transcript abundances are indicated by black circles.

\section{Conclusions}

We investigated the microbial community structure and gene expression in a severely $\mathrm{O}_{2}$-depleted anticyclonic modewater eddy in the open waters of the ETNA OMZ region. This was then compared to the eddy observations to background signals from the ETNA open-ocean CVOO time series site and the Mauritanian upwelling region, where the eddy was likely formed.

A significant difference between microbial communities outside and inside the eddy along with an overall loss in bacterial diversity in the low- $\mathrm{O}_{2}$ core of the eddy was observed. Similarity was found between the microbial community in the eddy core and on the shelf. This unique microbial community may shape the specific character of this $\mathrm{O}_{2}$-depleted eddy progressively over time.

We observed enhanced primary production in the eddy, presumably due to an increased nutrient supply related to the eddy dynamics (Karstensen et al. 2015b). We found a specific HNLC ecotype of Prochlorococcus, which may play a role in mediating inorganic $\mathrm{C}$ to certain organic $\mathrm{C}$ sources for the associated heterotrophic community present in the eddy. Importantly, we found the first indication for $\mathrm{N}$ loss processes in the ETNA region. Low- $\mathrm{O}_{2}$ eddies in that region thus represent an isolated ecosystem in the open ocean, forced by strongly elevated biological productivity, which travels with the eddy. This leads to consequent enhanced respiration and further deoxygenation in its core waters.

At one stage the low- $\mathrm{O}_{2}$ eddies will lose coherence and the extreme signatures will be released into and mixed with the surrounding waters (Karstensen et al., 2015a). The ACME formation frequency for the ETNA $\left(12-22^{\circ} \mathrm{N}\right.$ and $15-$ $26^{\circ} \mathrm{W}$ ) has been estimated to be about 2 to $3 \mathrm{yr}^{-1}$ (Schütte et al. 2015), hence no large-scale impact of the eddies are expected. However, an unexpected shift in elemental ratios or other anomalies, normally expected for regions with much lower minimal oxygen levels than the ETNA, may be detected and explained by the dispersal of low- $\mathrm{O}_{2}$ eddies. Another factor to consider is the impact of deoxygenation of the ETNA (Stramma et al., 2008) as it may result in even lower $\mathrm{O}_{2}$ conditions to be created in the low- $\mathrm{O}_{2}$ eddies. With regard to the distinct character of the low- $\mathrm{O}_{2}$ eddies and the critical shift in microbial diversity and biogeochemistry that occur over relatively short times, this study contributes to understand and evaluate the far-reaching effects of future and past ocean deoxygenation.

\section{The Supplement related to this article is available online at doi:10.5194/bg-12-7467-2015-supplement.}

Author contributions. C. R. Löscher designed the study together with B. Fiedler, A. Körtzinger, H. Hauss and J. Karstensen; M. Philippi and C. R. Löscher validated the NGS primer sets for marine samples, performed the molecular analysis, processed the molecular data and analyzed hydrographic data. S. Künzel performed the high-throughput sequencing runs. M. A. Fischer and S. C. Neulinger performed bioinformatic analysis of highthroughput data sets. A. Singh performed C-uptake measurements and data analysis, F. Philippi, J. Karstensen and A. Körtzinger designed the eddy detection and tracking system. B. Fiedler, F. Philippi, A. Körtzinger, H. Hauss and C. R. Löscher planned the sampling campaign and B. Fiedler performed hydrographical measurements and analyzed the data. S. C. Neulinger performed statistical analysis and modeling. C. R. Löscher wrote the manuscript with input from all co-authors.

Acknowledgements. We thank the authorities of Cape Verde and Mauritania for the permission to work in their territorial waters. We acknowledge the support of the captains and crews of R/V Islandia 
and R/V Meteor as well as the chief scientist of M105, M. Visbeck, for his spontaneous support. Moreover, we acknowledge I. Monteiro and M. Lohmann for performing oxygen and nutrient measurements, D. Grundle for sampling on R/V Islandia, C. Hoffman for technical assistance and the captains, crews and chief scientists of Meteor M107, S. Sommer and M. Dengler, for providing hydrographical data. We acknowledge H. Bange, G. Krahmann and R. Kiko for helpful discussion of the results. G. Petrick, flying to Cape Verde to repair the liquid $\mathrm{N}_{2}$ generator was priceless - we thank you a lot for this personal effort. We thank T. Treude for editing this manuscript. Further, we thank J. M. Beman and two anonymous reviewers for helpful discussion of the manuscript and A. Paul for language editing.

Financial support for this study was provided by a grant from the cluster of excellence "The Future Ocean" to C. R. Löscher, A. Körtzinger and H. Hauss. Authors C. R. Löscher, S. C. Neulinger, H. Hauss and M. Philippi were funded by the DFG Collaborative Research Centre754 (www.sfb754.de). M. A. Fischer was funded and S. C. Neulinger was co-funded by the BMBF project BioPara funded to R. A. Schmitz (grant no. 03SF0421B), A. Singh was funded by the cluster of excellence "The Future Ocean", B. Fiedler was funded by the BMBF project SOPRAN (grant no. 03F0662A).

Edited by: T. Treude

\section{References}

Ahlgren, N., Rocap, G., and Chisholm, S.: Measurement of Prochlorococcus ecotypes using real-time polymerase chain reaction reveals different abundances of genotypes with similar light physiologies, Environ. Microbiol., 8, 441-454, 2006.

Altabet, M. A., Ryabenko, E., Stramma, L., Wallace, D. W. R., Frank, M., Grasse, P., and Lavik, G.: An eddy-stimulated hotspot for fixed nitrogen-loss from the Peru oxygen minimum zone, Biogeosciences, 9, 4897-4908, doi:10.5194/bg-9-48972012, 2012.

Angel, R., Matthies, D., and Conrad, R.: Activation of Methanogenesis in Arid Biological Soil Crusts Despite the Presence of Oxygen, PlosOne, 6, e20453, doi:10.1371/journal.pone.0020453, 2011.

Arévalo-Martínez, D. L., Kock, A., Löscher, C. R., Schmitz, R. A., Stramma, L., and Bange, H. W.: Influence of mesoscale eddies on the distribution of nitrous oxide in the eastern tropical South $\mathrm{Pa}$ cific, Biogeosciences Discuss., 12, 9243-9273, doi:10.5194/bgd12-9243-2015, 2015.

Baird, M. E., Suthers, I. M., Griffin, D. A., Hollings, B., Pattiaratchi, C., Everett, J. D., Roughan, M., Oubelkheir, K., and Doblin, M.: The effect of surface flooding on the physical-biogeochemical dynamics of a warm-core eddy off southeast Australia, Deep-Sea Res. Pt. II, 58, 592-605, 2011.

Bauer, M., Kube, M., Teeling, H., Richter, M., Lombardot, T., Allers, E., Würdemann, C. A., Quast, C., Kuhl, H., Knaust, F., Woebken, D., Bischof, K., Mussmann, M., Choudhuri, J. V., Meyer, F., Reinhardt, R., Amann, R. I., and Glöckner, F. O.: Whole genome analysis of the marine Bacteroidetes'Gramella forsetii' reveals adaptations to degradation of polymeric organic matter, Environ. Microbiol., 8, 2201-2213, 2006.
Beman, J. M. and Carolan, M. T.: Deoxygenation alters bacterial diversity and community composition in the ocean's largest oxygen minimum zone, Nat. Commun., 4, 2705, doi:10.1038/ncomms3705, 2013.

Beman, J. M., Chow, C. E., King, A. L., Feng, Y. Y., Fuhrman, J. A., Andersson, A., Bates, N. R., Popp, B. N., and Hutchins, D. A.: Global declines in oceanic nitrification rates as a consequence of ocean acidification, P. Natl. Acad. Sci. USA, 108, 208-213, doi:10.1073/pnas.1011053108, 2011.

Benjamini, Y. and Hochberg, Y.: Controlling the false discovery rate: A practical and powerful approach to multiple testing, J. Roy. Stat. Soc. B, 57, 289-300, 1995.

Bertillson, S., Berglund, O., Pullin, M. J., and Chisholm, S. W.: Release of dissolved organic matter by Prochlorococcus, ie et milieu - Life and environment, 55, 225-231, 2005.

Berube, P. M., Biller, S. J., Kent, A. G., Berta-Thompson, J. W., Roggensack, S. E., Roache-Johnson, K. H., Ackerman, M., Moore, L. R., Meisel, J. D., Sher, D., Thompson, L. R., Campbell, L., Martiny A., and Chisholm, S. W.: Physiology and evolution of nitrate acquisition in Prochlorococcus, ISME J., 9, 11951207, doi:10.1038/ismej.2014.211, 2014.

Biller, S. J., Berube, P. M., Lindell, D., and Chisholm, S. W.: Prochlorococcus: the structure and function of collective diversity, Nat. Rev. Microbiol., 13, 13-27, 2015.

Brown, M. V., Ostrowski, M., Grzymski, J. J., and Lauro, F. M.: A trait based perspective on the biogeography of common and abundant marine bacterioplankton clades, Marine Genomics, 15, 17-28, 2014.

Bryant, J. A., Stewart, F. J., Eppley, J. M., and DeLong, E. F.: Microbial community phylogenetic and trait diversity declines with depth in a marine oxygen minimum zone, Ecology, 93, 16591673, 2012.

Buchan, A., LeCleir, G. R., Gulvik, C. A., and González, J. M.: Master recyclers: features and functions of bacteria associated with phytoplankton blooms, Nat. Rev. Microbiol., 12, 686-698, doi:10.1038/nrmicro3326, 2014.

Carini, P., Steindler, L., Beszteri, S., and Giovannoni, S. J.: Nutrient requirements for growth of the extreme oligotroph "Candidatus Pelagibacter ubique" HTCC1062 on a defined medium, ISME J., 7, 592-602, 2013.

Chavez, F. P. and Messié, M.: A comparison of Eastern Boundary Upwelling Ecosystems, Prog. Oceanogr., 83, 80-96, 2009.

Chelton, D. B., Gaube, P., Schlax, M. G., Early, J. J., and Samelson, R. M.: The Influence of Nonlinear Mesoscale Eddies on NearSurface Oceanic Chlorophyll, Science, 334, 328-332, 2011.

Chen, V. B., Davis, I. W., and Richardson, D. C.: KING (Kinemage, Next Generation): A versatile interactive molecular and scientific visualization program, Prot. Sci., 18, 2403-2409, doi:10.1002/pro.250, 2009.

Cole, J. R., Wang, Q., Fish, J. A., Chai, B., McGarrell, D. M., Sun, Y., Brown, C. T., Porras-Alfaro, A., Kuske, C. R., and Tiedje, J. M.: Ribosomal Database Project: data and tools for high throughput rRNA analysis, Nucleic Acids Res., 42, 633642, doi:10.1093/nar/gkt1244, 2014.

De Cáceres, M. and Legendre, P.: Associations between species and groups of sites: indices and statistical inference, Ecology, 90, 3566-3574, doi:10.1890/08-1823.1, 2009.

DeLong, E. F.: The microbial ocean from genomes to biomes, Nature, 459, 200-206, doi:10.1038/nature08059, 2009. 
DeSantis, T. Z., Hugenholtz, P., Larsen, N., Rojas, M., Brodie, E. L., Keller, K., Huber, T., Dalevi, D., Hu, P., and Andersen, G. L.: Greengenes, a chimera-checked 16S rRNA gene database and workbench compatible with ARB, Appl. Environ. Microb., 72, 5069-5072, doi:10.1128/aem.03006-05, 2006.

Deutsch, C., Sarmiento, J. L., Sigman, D. M., Gruber, N., and Dunne, J. P.: Spatial coupling of nitrogen inputs and losses in the ocean, Nature, 445, 163-167, doi:10.1038/nature05392, 2007.

Edgar, R. C., Haas, B. J., Clemente, J. C., Quince, C., and Knight, R.: UCHIME improves sensitivity and speed of chimera detection, Bioinformatics, 27, 2194-2200, doi:10.1093/bioinformatics/btr381, 2011.

Fernandez, C., Farias, L., and Ulloa, O.: Nitrogen Fixation in Denitrified Marine Waters, Plos One, 6, e20539, doi:10.1371/journal.pone.0020539, 2011.

Fiedler, B., Grundle, D., Hauss, H., Krahmann, G., Schütte, F., Monteiro, I., Silva, P., Vieira, N., and Körtzinger, A.: Biogeochemistry of oxygen depleted mesoscale Eddies in the open eastern tropical North Atlantic, Biogeosciences Discuss., in preparation, 2015.

Fierer, N., Hamady, M., Lauber, C. L., and Knight, R.: The influence of sex, handedness, and washing on the diversity of hand surface bacteria, P. Natl. Acad. Sci. USA, 105, 17994-17999, doi:10.1073/pnas.0807920105, 2008.

Fischer, G., Karstensen, J., Romero, O., Baumann, K.-H., Donner, B., Hefter, J., Mollenhauer, G., Iversen, M., Fiedler, B., Monteiro, I., and Körtzinger, A.: Bathypelagic particle flux signatures from a suboxic eddy in the oligotrophic tropical North Atlantic: production, sedimentation and preservation, Biogeosciences Discuss., 12, 18253-18313, doi:10.5194/bgd-12-18253-2015, 2015.

Flombaum, P., Gallegos, J. L., Gordillo, R. A; Rincon, J., Zabala, L. L., Jiao, N., Karld, D. M., Li, W. K. W., Lomas, M. W., Veneziano, D., Vera, C. S., Vrugt, J. A., and Martiny, A. C.: Present and future global distributions of the marine Cyanobacteria Prochlorococcus and Synechococcus, P. Natl. Acad. Sci. USA, 110, 9824-9829, 2013.

Forth, M., Liljebladh, B., Stigebrandt, A., Hall, P. O. J., and Treusch, A. H.: Effects of ecological engineered oxygenation on the bacterial community structure in an anoxic fjord in western Sweden, ISME J., 9, 656-669, doi:10.1038/ismej.2014.172, 2014.

Frank, D. N., St Amand, A. L., Feldman, R. A., Boedeker, E. C., Harpaz, N., and Pace, N. R.: Molecular-phylogenetic characterization of microbial community imbalances in human inflammatory bowel diseases, P. Natl. Acad. Sci. USA, 104, 13780-13785, doi:10.1073/pnas.0706625104, 2007.

Franz, J. M. S., Hauss, H., Sommer, U., Dittmar, T., and Riebesell, U.: Production, partitioning and stoichiometry of organic matter under variable nutrient supply during mesocosm experiments in the tropical Pacific and Atlantic Ocean, Biogeosciences, 9, 46294643, doi:10.5194/bg-9-4629-2012, 2012.

Ganesh, S., Parris, D. J., DeLong, E. F., and Stewart, F. J.: Metagenomic analysis of size-fractionated picoplankton in a marine oxygen minimum zone, ISME J., 8, 187-211, 2014.

Gao, H., Schreiber, F., Collins, G., Jensen, M. M., Kostka, J. E., Lavik, G., de Beer, D., Zhou, H.-Y., and Kuypers, M. M. M.: Aerobic denitrification in permeable Wadden Sea sediments, ISME J., 4, 417-426, 2010.
Giovannoni, S. J., Britschgi, T. B., Moyer, C. L., and Field, K. G.: Genetic diversity in Sargasso Sea bacterioplankton, Nature, 345, 60-63, doi:10.1038/345060a0, 1990.

Glöckner, F. O., Fuchs, B. M., and Amann, R.: Bacterioplankton compositions of lakes and oceans: a first comparison based on fluorescence in situ hybridization, Environ Microbiol., 65, 37213726, 1999.

Grasshoff, G., Kremling, K., and Erhardt, M.: Methods of seawater analysis, 3 Edn., Wiley VCH, Weinheim, 1999.

Grundle, D. S., Löscher, C. R., Krahmann, G., Altabet, M. A., Bange, H. W., Karstensen, J., Körtzinger, A., and Fiedler, B.: Extreme $\mathrm{N}_{2} \mathrm{O}$ activity in an oxygenated ocean, Nature Scientific Reports, submitted, 2015.

Hauss, H., Christiansen, S., Schütte, F., Kiko, R., Edvam Lima, M., Rodrigues, E., Karstensen, J., Löscher, C. R., Körtzinger, A., and Fiedler, B.: Dead zone or oasis in the open ocean? Zooplankton distribution and migration in low-oxygen modewater eddies, Biogeosciences Discuss., 12, 18315-18344, doi:10.5194/bgd12-18315-2015, 2015.

Hood, E. M., Sabine, C. L., and Sloyan, B. M.: The GO-SHIP Repeat Hydrography Manual: A Collection of Expert Reports and Guidelines, IOCCP Report Number 14, ICPO Publication Series Number 134, available at: http://www.go-ship.org/HydroMan. html (last access: 19 March 2013), 2010.

Jickells, T. D., An, Z. S., Andersen, K. K., Baker, A. R., Bergametti, G., Brooks, N., Cao, J. J., Boyd, P. W., Duce, R. A., Hunter, K. A., Kawahata, H., Kubilay, N., laRoche, J., Liss, P. S., Mahowald, N., Prospero, J. M., Ridgwell, A. J., Tegen, I., and Torres, R.: Global iron connections between desert dust, ocean biogeochemistry, and climate, Science, 308, 67-71, 2005.

Jost, L.: Entropy and diversity, Oikos, 113, 363-375, doi:10.1111/j.2006.0030-1299.14714.x, 2006.

Jost, L.: Partitioning diversity into independent alpha and beta components, Ecology, 88, 2427-2439, doi:10.1890/06-1736.1, 2007.

Kalvelage, T., Lavik, G., Lam, P., Contreras, S., Artega, L., Löscher, C. R., Oschlies, A., Paulmier, A., Stramma, L., and Kuypers, M. M. M.: Nitrogen cycling driven by organic matter export in the South Pacific oxygen minimum zone, Nat. Geosci., 6, 228-234, 2013.

Karstensen, J., Stramma, L., and Visbeck, M.: Oxygen minimum zones in the eastern tropical Atlantic and Pacific oceans, Prog Oceanogr., 77, 331-350, doi:10.1016/j.pocean.2007.05.009, 2008.

Karstensen, J., Fiedler, B., Schütte, F., Brandt, P., Körtzinger, A., Fischer, G., Zantopp, R., Hahn, J., Visbeck, M., and Wallace, D.: Open ocean dead zones in the tropical North Atlantic Ocean, Biogeosciences, 12, 2597-2605, doi:10.5194/bg-12-2597-2015, 2015a.

Karstensen, J., Schütte, F., Pietri, A., Krahmann, G., Fiedler, B., Körtzinger, A., Löscher, C. R., Grundle, D., and Hauss, H.: Anatomy of open ocean dead-zones based on high-resolution multidisciplinary glider data, Biogeosciences Discuss., in preparation, 2015b.

Kozich, J. J., Westcott, S. L., Baxter, N. T., Highlander, S. K., and Schloss, P. D.: Development of a dual-index sequencing strategy and curation pipeline for analyzing amplicon sequence data on the MiSeq Illumina sequencing platform, Appl. Environ. Microb., 79, 5112-5120, doi:10.1128/aem.01043-13, 2013. 
Lam, P., Jensen, M. M., Lavik, G., McGinnis, D. F., Muller, B., Schubert, C. J., Amann, R., Thamdrup, B., and Kuypers, M. M. M.: Linking crenarchaeal and bacterial nitrification to anammox in the Black Sea, P. Natl. Acad. Sci. USA, 104, 7104-7109, doi:10.1073/pnas.0611081104, 2007.

Langfeldt, D., Neulinger, S. C., Heuer, W., Staufenbiel, I., Künzel, S., Baines, J. F., Eberhard, J., and Schmitz, R. A.: Composition of microbial oral biofilms during maturation in young healthy adults, PlosOne, 9, e87449, doi:10.1371/journal.pone.0087449, 2014.

Langlois, R. J., Hummer, D., and LaRoche, J.: Abundances and distributions of the dominant nifH phylotypes in the Northern Atlantic Ocean, Appl. Environ. Microb., 74, 1922-1931, doi:10.1128/aem.01720-07, 2008.

Lévy, M., Klein, P., and Treguier, A.-M.: Impacts of sub-mesoscale physics on phytoplankton production and subduction, J. Mar. Res., 59, 535-565, doi:10.1357/002224001762842181, 2001.

Lévy, M., Ferrari, R., Franks, P. J. S., Martin, A. P., and Riviere, P.: Bringing physics to life at the submesoscale, Geophys. Res. Lett., 39, L14602, doi:10.1029/2012g1052756, 2012.

Löscher, C. R., Kock, A., Könneke, M., LaRoche, J., Bange, H. W., and Schmitz, R. A.: Production of oceanic nitrous oxide by ammonia-oxidizing archaea, Biogeosciences, 9, 2419-2429, doi:10.5194/bg-9-2419-2012, 2012.

Löscher, C. R., Großkopf, T., Desai, F., Gill, D., Schunck, H., Croot, P., Schlosser, C., Neulinger, S. C., Lavik, G., Kuypers, M. M. M., LaRoche, J., and Schmitz, R. A.: Facets of diazotrophy in the oxygen minimum zone off Peru, ISME J., 8, 2180-2192, doi:10.1038/ismej.2014.71, 2014.

Löscher, C. R., Bange, H. W., Schmitz, R. A., Callbeck, C. M., Engel, A., Hauss, H., Kanzow, T., Kiko, R., Lavik, G., Loginova, A., Melzner, F., Neulinger, S. C., Pahlow, M., Riebesell, U., Schunck, H., Thomsen, S., and Wagner, H.: Water column biogeochemistry of oxygen minimum zones in the eastern tropical North Atlantic and eastern tropical South Pacific Oceans, Biogeosciences Discuss., 12, 4495-4556, doi:10.5194/bgd-12-44952015, 2015.

Mahadevan, A.: Ocean science: Eddy effects on biogeochemistry, Nat. Geosci., 506, 168-169, doi:10.1038/nature13048, 2014.

McGillicuddy, D. J., Anderson, L. A., Bates, N. R., Bibby, T., Buesseler, K. O., Carlson, C. A., Davis, C. S., Ewart, C., Falkowski, P. G., Goldthwait, S. A., Hansell, D. A., Jenkins, W. J., Johnson, R., Kosnyrev, V. K., Ledwell, J. R., Li, Q. P., Siegel, D. A., and Steinberg, D. K.: Eddy/wind interactions stimulate extraordinary mid-ocean plankton blooms, Science, 316, 1021-1026, doi:10.1126/science.1136256, 2007.

Morris, J. J., Kirkegaard, R., Szul, M. J., Johnson, Z. I., and Zinser, E. R.: Facilitation of robust growth of Prochlorococcus colonies and dilute liquid cultures by "helper" heterotrophic bacteria, Appl. Environ. Microb., 74, 4530-4534, 2008.

Morris, R. M., Rappé, M. S., Connon, S. A., Vergin, K. L., Siebold, W. A., Carlson, C. A., and Giovannoni, S. J.: SAR11 clade dominates ocean surface bacterioplankton communities, Nature, 420, 806-810, doi:10.1038/nature01240, 2002.

Oksanen, J., Blanchet, F. G., Kindt, R., Legendre, P., and Minchin, P. R.: vegan: Community ecology package, $R$ package version 2.0-6., 2013.
Oschlies, A. and Garcon, V.: Eddy-induced enhancement of primary production in a model of the North Atlantic Ocean, Nature, 394, 266-269, 1998.

Parsons, T. R., Maita, Y., and Lalli, C. M.: A Manual of Chemical and Biological Methods for Seawater Analysis, Pergamon Press, Oxford, 173 pp., 1984.

Pinheiro, J. C., Bates, D. M., DebRoy, S., Sarkar, D., and R Core Team: nlme: Linear and nonlinear mixed effects models, R package version 3.1-120 ed., 2015.

Poretsky, R. S., Hewson, I., Sun, S. L., Allen, A. E., Zehr, J. P., and Moran, M. A.: Comparative day/night metatranscriptomic analysis of microbial communities in the North Pacific subtropical gyre, Environ. Microbiol., 11, 1358-1375, doi:10.1111/j.14622920.2008.01863.x, 2009.

Pruesse, E., Quast, C., Knittel, K., Fuchs, B. M., Ludwig, W., Peplies, J., and Glöckner, F. O.: SILVA: a comprehensive online resource for quality checked and aligned ribosomal RNA sequence data compatible with ARB, Nucleic Acids Res., 35, 7188-7196, doi:10.1093/nar/gkm864, 2007.

Rappé, M. S., Connon, S. A., Vergin, K. L., and Giovannoni, S. J.: Cultivation of the ubiquitous SAR11 marine bacterioplankton clade, Nature, 418, 630-633 doi:10.1038/nature00917, 2002.

R Core Team: R: A language and environment for statistical computing, R Foundation for Statistical Computing, Vienna, Austria, 2015.

Richardson, D. C. and Richardson, J. S.: The kinemage: A tool for scientific communication, Protein Sci., 1, 3-9, doi:10.1002/pro.5560010102, 1992.

Riebesell, U. and Gattuso, J.-P.: Lessons learned from ocean acidification research, Nature Climate Change, 5, 12-14, doi:10.1038/nclimate2456, 2015.

Ryabenko, E., Kock, A., Bange, H. W., Altabet, M. A., and Wallace, D. W. R.: Contrasting biogeochemistry of nitrogen in the Atlantic and Pacific Oxygen Minimum Zones, Biogeosciences, 9, 203215, doi:10.5194/bg-9-203-2012, 2012.

Schloss, P. D., Westcott, S. L., Ryabin, T., Hall, J. R., Hartmann, M., Hollister, E. B., Lesniewski, R. A., Oakley, B. B., Parks, D. H., Robinson, C. J., Sahl, J. W., Stres, B., Thallinger, G. G., Van Horn, D. J., and Weber, C. F.: Introducing mothur: Open-source, platform-independent, community-supported software for describing and comparing microbial communities, Appl. Environ. Microb., 75, 7537-7541, doi:10.1128/aem.01541-09, 2009.

Schmid, M. C., Hooper, A. B., Klotz, M. G., Woebken, D., Lam, P., Kuypers, M. M. M., Pommerening-Roeser, A., op den Camp, H. J. M., and Jetten, M. S. M.: Environmental detection of octahaem cytochrome c hydroxylamine/hydrazine oxidoreductase genes of aerobic and anaerobic ammonium-oxidizing bacteria, Environ. Microbiol., 10, 3140-3149, doi:10.1111/j.14622920.2008.01732.x, 2008.

Schütte, F., Karstensen, J., Krahmann, G., Fiedler, B., Brandt, P., Visbeck, M., and Körtzinger, A.: Characterization of "dead-zone eddies" in the tropical North Atlantic Ocean, Biogeosciences Discuss., in preparation, 2015.

Stewart, F. J., Ulloa, O., and DeLong, E. F.: Microbial metatranscriptomics in a permanent marine oxygen minimum zone, Environ. Microbiol., 14, 23-40, doi:10.1111/j.14622920.2010.02400.x, 2011. 
Stramma, L., Johnson, G. C., Sprintall, J., and Mohrholz, V.: Expanding oxygen-minimum zones in the tropical oceans, Science, 320, 655-658, doi:10.1126/science.1153847, 2008.

Stramma, L., Bange, H. W., Czeschel, R., Lorenzo, A., and Frank, M.: On the role of mesoscale eddies for the biological productivity and biogeochemistry in the eastern tropical Pacific Ocean off Peru, Biogeosciences, 10, 7293-7306, doi:10.5194/bg-10-72932013, 2013.

Stratil, S. B., Neulinger, S. C., Knecht, H., Friedrichs, A. K., and Wahl, M.: Temperature-driven shifts in the epibiotic bacterial community composition of the brown macroalga Fucus vesiculosus, MicrobiologyOpen, 2, 338-349, doi:10.1002/mbo3.79, 2013.

Stratil, S. B., Neulinger, S. C., Knecht, H., Friedrichs, A. K., and Wahl, M.: Salinity affects compositional traits of epibacterial communities on the brown macroalga Fucus vesiculosus, FEMS Microbiol. Ecol., 88, 272-279, doi:10.1111/1574-6941.12292, 2014.

Suzuki, M., Preston, C., Chavez, F., and DeLong, E.: Quantitative mapping of bacterioplankton populations in seawater: field tests across an upwelling plume in Monterey Bay, Aquat. Microb. Ecol., 24, 117-127, 2001.

Swan, B. K., Martinez-Garcia, M., Preston, C. M., Sczyrba, A., Woyke, T., Lamy, D., Reinthaler, T., Poulton, N. J., Masland, E. D. P., Gomez, M. L., Sieracki, M. E., DeLong, E. F., Herndl, G. J., and Stepanauskas, R.: Potential for chemolithoautotrophy among ubiquitous bacteria lineages in the dark ocean, Science, 333, 1296-1300, doi:10.1126/science.1203690, 2011.

Ulloa, O., Canfield, D. E., DeLong, E. F., Letelier, R. M., and Stewart, F. J.: Microbial oceanography of anoxic oxygen minimum zones, P. Natl. Acad. Sci. USA, 109, 15996-16003, doi:10.1073/pnas.1205009109, 2012.
Vaquer-Sunyer, R. and Duarte, C. M.: Thresholds of hypoxia for marine biodiversity, P. Natl. Acad. Sci. USA, 105, 15452-15457, 2008.

Wang, Q., Garrity, G. M., Tiedje, J. M., and Cole, J. R.: Naïve Bayesian Classifier for Rapid Assignment of rRNA Sequences into the New Bacterial Taxonomy, Appl. Environ. Microb., 73, 5261-5267 doi:10.1128/AEM.00062-07, 2007.

West, N. J., Lebaron, P., Strutton, P. G., and Suzuki, M. T.: A novel clade of Prochlorococcus found in high nutrient low chlorophyll waters in the South and Equatorial Pacific Ocean, ISME J., 5, 933-944, 2011.

Wright, J. J., Konwar, K. M., and Hallam, S. J.: Microbial ecology of expanding oxygen minimum zones, Nat. Rev. Microbiol., 10, 381-394, doi:10.1038/nrmicro2778, 2012.

Yu, Y., Lee, C., Kim, J., and Hwang, S.: Group-specific primer and probe sets to detect methanogenic communities using quantitative real-time polymerase chain reaction, Biotechnol. Bioeng., 89, 670-679, doi:10.1002/bit.20347, 2005.

Zhu, M., and Ghodsi, A.: Automatic dimensionality selection from the scree plot via the use of profile likelihood, Comput. Stat. Data An., 51, 918-930, doi:10.1016/j.csda.2005.09.010, 2006.

Zuur, A. F., Ieno, E. N., Walker, N. J., Saveliev, A. A., and Smith, G. M.: Mixed effects models and extensions in ecology with R, Statistics for Biology and Health, edited by: Gail, M., Krickeberg, K., Samet, J. M., Tsiatis, A., and Wong, W., Springer, New York, USA, 2009. 